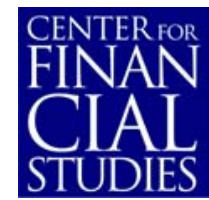

No. $2004 / 05$

Private Equity Returns And Disclosure Around The World

Uwe Walz, Douglas Cumming 


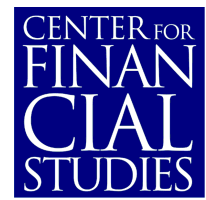

\section{Center for Financial Studies}

The Center for Financial Studies is a nonprofit research organization, supported by an association of more than 120 banks, insurance companies, industrial corporations and public institutions. Established in 1968 and closely affiliated with the University of Frankfurt, it provides a strong link between the financial community and academia.

The CFS Working Paper Series presents the result of scientific research on selected topics in the field of money, banking and finance. The authors were either participants in the Center's Research Fellow Program or members of one of the Center's Research Projects.

If you would like to know more about the Center for Financial Studies, please let us know of your interest.

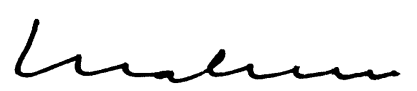

Prof. Dr. Jan Pieter Krahnen

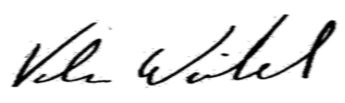

Prof. Volker Wieland, Ph.D. 


\title{
Private Equity Returns And Disclosure Around The World
}

\author{
Uwe Walz*, Douglas Cumming ${ }^{+}$
}

\author{
March 2004
}

\begin{abstract}
:
We study the returns the venture capital and private equity investment from 221 venture capital and private equity funds that are part of 72 venture capital and private equity firms, 5040 entrepreneurial firms (3826 venture capital and 1214 private equity), and spanning 32 years $(1971$ - 2003) and 39 countries from North and South America, Europe and Asia. We make use of four main categories of variables to proxy for value-added activities and risks that explain venture capital and private equity returns: market and legal environment, VC characteristics, entrepreneurial firm characteristics, and the characteristics and structure of the investment. We show Heckman sample selection issues in regards to both unrealized and partially realized investments are important to consider for analysing the determinants of realized returns. We further compare the actual unrealized returns, as reported to investment managers, to the predicted unrealized returns based on the estimates of realized returns from the sample selection models. We show there exists significant systematic biases in the reporting of unrealized investments to institutional investors depending on the level of the earnings aggressiveness and disclosure indices in a country, as well as proxies for the degree of information asymmetry between investment managers and venture capital and private equity fund managers.
\end{abstract}

JEL Classification: G24, G28, G31, G32, G35

Keywords: Venture Capital, Private Equity, Risk, Return, Law and Finance

Acknowledgements. We owe thanks to the finance workshop participants at the J.W. Goethe-Universität Frankfurt/Main. We are grateful to CEPRES (Center for Private Equity Research, Frankfurt), especially Daniel Schmidt and the Center for Financial Studies (Frankfurt) for funding and data.

* Uwe Walz, J.W. Goethe-Universität Frankfurt/Main, Schumannstr. 60, Uni-PF 64, 60054 Frankfurt/Main, Germany, Tel.: ++49-69-798-22775, Fax:++49-798-22753,Email: uwe.walz@,wiwi.uni-frankfurt.de, http://www.wiwi.uni-frankfurt.de/profs/walz and Center for Financial Studies, Taunusanlage 6, 60329 Frankfurt/Main, Germany

${ }^{+}$Douglas Cumming, University of Alberta School of Business, Edmonton, Alberta, Canada T6G 2R6 Tel: 001-780-492-0678, Fax: 001-780-492-3325, Email: douglas.cumming@ualberta.ca http://www.bus.ualberta.ca/dcumming/ 


\section{Introduction}

Perhaps one of the most well-known issues pertaining to venture capital in the popular press in 2002 and 2003 involved the 'transparency lawsuits' in which public pension funds such as CalPERS, the largest pension fund in the U.S., were forced to disclose the performance results of venture capital funds to the public. Venture capital funds have been vigorously opposed to disclosure of their IRRs, particularly in the aftermath of the collapse of the Internet bubble. ${ }^{1}$ Such disclosure has had drastic implications for the venture capital industry in the U.S. For example, some venture capital funds have restricted participation from limited partners that may end up disclosing their performance results, ${ }^{2}$ and likewise, some pension funds have been forced to rethink their investment strategy into

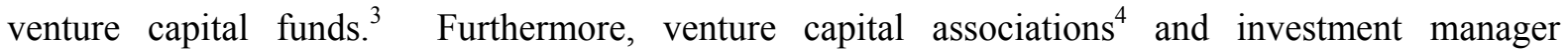
associations $^{5}$ more generally around the world have now been reconsidering the issue as to the appropriate standards for reporting unrealized returns to institutional investors.

These industry developments which have take place against the background of wide variations in success of venture capitalists in their portfolio firms give rise to the following research questions. First, how should the risk and return to venture capital and private equity on reported and unreported investments be estimated and what determines the performance of venture capitalists in their portfolio firms? Second, do biases exist in the reporting of unrealized investments to institutional investors, and if so, under what conditions are those biases more pronounced? These issues are of interest to venture capital and private equity industries around the world.

In this paper, we investigate the determinants of realized internal rates of return (IRRs) based on an international sample of venture capital and private equity investments around the world. We introduce new methods for measuring venture capital and private equity IRRs, and show that these methods have a significantly improved ability to explain realized returns relative to prior papers in the literature on the risk and return to venture capital. We then focus our attention towards the reporting of unrealized IRRs by venture capital and private equity managers to their institutional investors. We show the existence of systematic biases in reporting that are related to accounting disclosure measures

\footnotetext{
1 For example, see, http://www.ventureeconomics.com/vec/1031550742742.html < accessed 11 January 2004>.

2 For example, Sequoia Capital has ejected the University of Michigan; http://www.mercurynews.com/mld/mercurynews/business/6390139.htm < accessed 11 January 2004>

For example, CalPERS has been forced to reconsider its venture capital allocations, and in ways that differ relative to what it might otherwise have done but for the public disclosure; see http://www.ventureeconomics.com/vcj/protected/1070549534318.html < accessed 11 January 2004>

4 See, e.g., http://www.evca.com/html/PE industry/IS.asp < accessed 11 January 2004>

5 The Association for Investment Management and Research (AIMR), perhaps the leading international self regulatory organization around the world for investment managers, released new guidelines in September 2003; see http://www.aimr.org/pdf/standards/ipc/sept03/10a.pdf < accessed 11 January 2004>. As well, the National Venture Capital Association recently (as at 3 March 2004) rejected a proposal by the Private Equity Industry Guidelines Group regarding valuation guidelines, creating controversies among the Institutional Limited Partners Association and other industry associations; see http://www.privateequityonline.com/TopStory.asp?ID=4498\&strType=1 <accessed 4 March 2004>.
} 
across countries, and proxies for information asymmetry between the venture capital and private equity fund managers and their institutional investors. We show biases in the reporting of unrealized investments are related to fundraising.

Our empirical analysis is based on theoretical approaches which allow us to derive testable hypotheses which are then investigated in our empirical work. We distinguish between two areas. In a first step we provide a theoretical framework allowing us to derive hypotheses on the determinants of $\mathrm{VC}$ returns on the investment in their portfolio firm. Our main argument rests on the value-added contribution of the venture capital. We derive various hypotheses related to this value-added approach such as a positive relationship between the monitoring intensity of $\mathrm{VC}$ funds as well as the positive effect of the legal and economic environment for the success of the VC. For the second pillar of our paper, namely the reporting of valuations of unexited investments, we focus on the trade-off between reputational concerns of the $\mathrm{VC}$ funds and their objective to facilitate fundraising in the next round. Whereas reputational concerns which are hurt by too high valuation create an incentive to report the value of portfolio firms correctly, higher valuation increase the probability of successful fundraising in the next period. This trade-off which is analysed in an asymmetric information setting enables us to point to factors (such as less stringent accounting rules, early-stage investments) which increase (or decrease) the incentives to report high values.

In our empirical analysis, we study the returns the venture capital and private equity investment from 221 venture capital and private equity funds that are part of 72 venture capital and

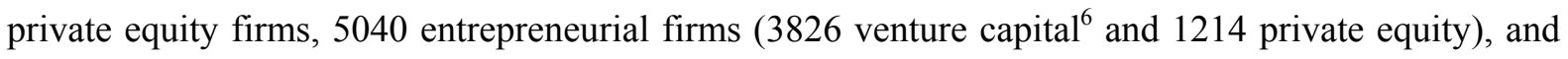
spanning 32 years $(1971$ - 2003) and 39 countries from North and South America, Europe and Asia. Making use of the fact that we have information on all the cashflows between the $\mathrm{VC}$ and the portfolio firm, we can calculate precisely the actual IRR from all cashflows (see for further details Schmidt (2003) and Schmidt et al (2003)) rather than having to rely than having to rely on a proxy for returns computed from initial and final cashflows (see e.g. Cochrane, 2001, and Ljungqvist/Richardson, 2003, on the use of proxies).

We build on prior work on measuring the risk and return to venture capital based on U.S. data with sample selection corrections in regards to exit versus non-exit (Cochrane, 2001). Our empirical methods make use of bivariate Heckman sample selection procedures in order to account for selection effects in regards to exited versus unexited investments (like Cochrane, 2001), as well as full versus partially exited investments (as an extension to Cochrane, 2001). We show that sample selection

\footnotetext{
We refer to venture capital in this paper as seed, start-up, early stage and expansion investing (defined in Table 1). Our definition of venture capital follows that put forth by Venture Economics in the U.S. (www.ventureeconomics.com) and the European Venture Capital Association (www.evca.com). We control for investment stages, and none of our results are not contingent on the definition of the sample (we explicitly report results for the full sample and the subsample of venture capital, and other subsamples are available upon request).
} 
effects are important to consider in both dimensions in measuring the determinants of venture capital and private equity IRRs. Our work is also related to papers that investigate performance on a portfolio approach, including Schmidt (2003) and Schmidt et al. (2003).

We make use of four main categories of variables to proxy for value-added activities and risks that explain venture capital and private equity returns: market and legal environment, $\mathrm{VC}$ characteristics, entrepreneurial firm characteristics, and the characteristics and structure of the investment. While prior work on topic (based on U.S. data) has been able to explain up to only $1 \%$ percent of the variation in IRRs (Cochrane, 2001), ${ }^{7}$ our approach enables up to $36 \%$ of the variation in IRRs to be explained. We find that the VC, entrepreneur and investment characteristics, as well as the economic environment, all attribute significantly to the success of $\mathrm{VC}$ investment. We also show that the legal framework in the different countries we have in our sample significantly contributes to the performance of VC investment: the more sound the legal conditions, the higher the IRRs. Much in line with our theory we are able to reveal that monitoring intensity significantly increases the IRRs of exited investments. As with monitoring intensity our findings on control instruments and incentivecompatible instruments support our (and others) theoretical reasoning: syndicated investments and investments in which convertible securities are used do yield significantly higher IRRs for the VCs.

We then extend our analysis to consider the unexited IRRs, as reported by the venture capital and private equity fund managers to their institutional investors. While some work in the past has considered the issue of measuring the risk and return to venture capital, as discussed, no prior paper has considered the issue of reporting of unrealized returns to institutional investors. In our paper, we compare the reported IRRs on unexited investments to what we would predict for such unrealized investments, based on our analysis of realized investments. We show that there are systematic biases in the reporting of unexited IRRs relative to what we would expect. These reporting biases are explained in terms of cross-country differences in accounting standards (in the spirit of Bhattacharya, Daouk and Welker, 2003), legality (in the spirit of La Porta et al., 1997, 1998; Berkowitz et al., 2003), and proxies for information asymmetry between venture capital and private equity fund managers and their institutional investors (in the spirit of Gompers and Lerner, 1996, 1999). We thereby provide empirical evidence for our hypothesis that the costs of overreporting (higher losses of reputation in countries with a more sound legal system) are negatively related to the valuations of unexited investments. In addition, in line with our theoretical analysis we can show that experienced VCs (with a reputational capital stock which is jeopardized with too high valuations) tend to report significantly lower valuation than their younger counterparts. Furthermore, it turns out that early stage and high-tech unexited investments are, on average, valued higher than what we would predict based

Ljungqvist and Richardson (2003b) are able to explain up to $12.7 \%$ in the variation in returns, but that paper does not consider selection effects (or at least selection effects are not discussed or explicitly considered in that paper). 
on realized early stage high-tech investments. Overall, given our four categories of control variables enumerated above, the Heckman selection bias is such that reported unrealized returns are higher than actual realized returns.

This paper is organized as follows. A theoretical model outlining the economic issues considered herein is presented in section 2. The data are described in section 3. Section 4 provides an analysis of realized IRRs with consideration to sample selection issues. Section 5 compares unrealized IRRs to predicted IRRs. A discussion of limitations and extensions is provided in section 6. The last section concludes.

\section{Theoretical Framework and Hypotheses}

In this section we will outline a brief theoretical framework which allows us to derive testable hypotheses for our empirical investigation. We distinguish between the analysis of the determinants of returns (2.1) and the investigation of potential reasons for overreporting unexited investments (2.2).

\subsection{Advice and Montoring Activities as Drivers of Returns}

We consider in this section two main drivers of VC's returns from investing in their portfolio firm. That is, we do not point to the characteristics of the firm but rather to the $\mathrm{VC}$ as the main source of higher IRR. This is quite straightforward. Investing in a successful firm with a high expected rate of return on equity is by no means equivalent to a high rate of return for the VC. If the high expected return is commonly expected this implies that the VC has to pay a high price for a given number of shares. That is, through this direction other than normal (risk-adjusted) rates of returns are not possible.

If the $\mathrm{VC}$, however, is able to provide more advice and is more capable in selecting highprofile firms, this can lead to higher IRRs. We want to explore especially the impact of the VCs monitoring and advice contribution in more detail. Thereby we consider advice in a rather general setup: not only as advice in the narrow sense but also all kind of monitoring and control activities.

The set-up: A portfolio firm is facing a number of VCs willing to invest in the firm the amount I. There are two potential outcomes from the investment. With probability $\mathrm{p}($.$) the project is$ successful leading to a firm value $\mathrm{V}=\bar{V}$. With probability (1-p) the projects fails leading to the firm value $\mathrm{V}=0$. The probability of success hinges essentially on the level of advice (including monitoring and control activities) contributed by the VC. We denote this by a. If the VC provides advice, it has to bear costs $C(a)$ and the firm faces the higher probability of success $p(a)$. We are more specific by 
assuming a linear relationship between advice, i.e. $\mathrm{p}(\mathrm{a})=\mathrm{a}(\mathrm{a} \varepsilon(0,1))$ and costs that are increasing in the level of advice, $\mathrm{C}()=.\mathrm{ca}^{2}$, whereby $\mathrm{c}$ is the efficiency parameter of the respective VC. The VCs differ in their respective advice and monitoring technology (depicted by $\mathrm{c}$ ). If the VC provides no effort, the probability of success of is denoted by $p<p(a)$; no costs occur.

Given all this, the entrepreneurial firm maximizes the following program:

(A.1) $\quad \operatorname{Max} \mathrm{p}(\mathrm{a})(1-\theta) \bar{V}$

s.t.

$$
\text { p(a) } \theta \bar{V}-\mathrm{ca}^{2}-\mathrm{I} \geq 0
$$

with $\theta$ denoting the VC's share in the firm.

The restriction (A.2) displays the participation constraint of the VC. The incentive compatibility constraint (for providing high quality a) is assumed to be fulfilled for all VCs. Due to competition in the VC sector, the participation constraint of the VC is always binding. Hence, we can use (A.2) in (A.1) to rewrite the maximization problem to:

$$
\operatorname{Max}\left(\text { a) } \quad \text { a } \bar{V}-\mathrm{ca}^{2}-\mathrm{I}\right.
$$

The first-order condition to this can be written as:

$$
\bar{V}-2 \mathrm{ca}=0
$$

leading to

$$
\mathrm{a}^{*}=\bar{V} / 2 \mathrm{c}
$$

The optimal rate of advice chosen is hence decreasing in $\mathrm{c}$ : the more efficient the $\mathrm{VC}$ is, the higher the level of advice. Plugging this result in the monetary return of the VC yields:

$$
\text { p(a) } \theta \bar{V}=\mathrm{C}\left(\mathrm{a}^{*}\right)+\mathrm{I}=\left(\bar{V}^{2} / 4 \mathrm{c}\right)+\mathrm{I}
$$


That is, the more efficient the $\mathrm{VC}$ is (the smaller $\mathrm{c}$ is) the larger the level of advice chosen and the higher the monetary (rate) of return of the VC.

Interpreting the efficiency level of the $\mathrm{VC}$ in broad term leads us to the following hypotheses:

The higher the intensity of monitoring and advice the higher the expected IRR of the VC

$>$ A more intensive use of monitoring and control devices (like convertibles, syndication etc) leads to a higher expected rate of return

$>$ The better the (legal and economic) framework the $\mathrm{VC}$ operates in, the higher its efficiency (in advice) and the higher the expected rates of returns.

\subsection{Reporting and Overvaluations}

We will present in this section a model in which VCs decide upon reporting truthfully or too high firm values to the potential investors. In order to carve out the same mechanisms we consider a very stylized set-up.

There are two potential projects VCs have invested in: successful and less successful one. Exante these two outcome are equally likely. The firm value of the former is denoted by $\bar{V}$, whereas the latter's value is $\underline{\mathrm{V}}$ (with $\bar{V}>\underline{\mathrm{V}}$ ). The $\mathrm{VC}$ can either report the true value (denoted by $\mathrm{V}$ ) of the respective portfolio firm or overstate the valuation. There are three different feasible valuations (V') which can be reported to potential investors: $\mathrm{V}^{\mathrm{l}}=\underline{\mathrm{V}} ; \mathrm{V}^{\mathrm{m}}=\bar{V}$, and finally $\mathrm{V}^{\mathrm{h}}>\bar{V}$. In essence, this implies that overvaluation of good firms does not work since announcing $\mathrm{V}^{\mathrm{h}}$ is completely uninformative for potential investors. Since there is no gain to quote $\mathrm{V}^{\mathrm{h}}$ but a potential cost, we will never observe $\mathrm{V}^{\mathrm{h}}$ in equilibrium.

There are two types of venture capitalists: those with little reputational capital (inexperienced VCs) and a second group of venture capitalists (experienced ones) which have acquired a high reputational capital stock. The VCs are maximizing their objective function which consists of the reputational stock and the gains from raising a new fund in the next period. The probability to raise a new fund hinges on the difference between the reported valuation (as perceived by investors $(\tilde{V})$ ) and the average value of the portfolio firms: $\mathrm{V}$ ' $=(\bar{V}+\underline{\mathrm{V}}) / 2$ 
By choosing the reported value of the entrepreneurial firm the VC maximizes the objective function consisting of the sum of reputational capital and the discounted value of the expected profits resulting from successful fundraising:

$$
r\left(b+a\left(V-V^{\prime}\right)\right)+p\left(\tilde{V}-V^{\prime}\right) F \quad \text { with } \mathrm{a}>0 ; \mathrm{p}>0 \text { and } \mathrm{b}>\mathrm{a}(\bar{V}-\underline{\mathrm{V}})
$$

whereby $r$ denotes the parameter denoting the reputational impact of (over-)valuation. The size of the investment is denoted by $\mathrm{F}$. We assume that overvaluation reduces the reputation of a $\mathrm{VC}$ significantly but not entirely, $\mathrm{b}>\mathrm{a}(\bar{V}-\underline{\mathrm{V}})$. Inexperienced VCs have a very low reputational capital stock $\left(r_{U}=0\right)$ whereas experienced ones can rely on their past track record $\left(r_{E}>0\right)$. The impact of (over)valuation depends on the accounting rules under which the valuation takes place (measured by a). The more stringent these rules are (i.e. the larger a, the more pronounced is the effect of overvaluation on the reputational capital stock.

Due to our very stylized set-up there are only two potential equilibria. Either all VCs report $\mathrm{V}^{\mathrm{m}}$, i.e. the overreport the value of their unsuccessful venture (the pooling equilibrium) or the experienced ones report the true value of their firms whereas the inexperienced ones always have an incentive to overstate ( a semi-separating equilibrium). Before we analyse which of these two equilibria emerges, we first have to show that the inexperience investors always have an incentive to overreport.

If an inexperienced VCs overstates the value of its investment, there is no cost to it since $r_{U}$ $=0$. But, reporting $\mathrm{V}^{\mathrm{m}}$ does not lead to an increase in the probability to raise the next fund either (since the valuation perceived by the investors and the average valuations are the same). But, still, $\mathrm{V}^{\mathrm{m}}$ is a dominant strategy for the individual $\mathrm{VC}$ since reporting the true value would potentially lower $\mathrm{p}$ (in the case of an unsuccessful) venture. Hence, the inexperienced VC never has an incentive to deviate from neither the pooling Nash equilibrium nor from the semi-separating equilibrium.

When does an experienced VC overstate, when does a pooling equilibrium emerge? An experienced $\mathrm{VC}$ compares the difference in total payoff from reporting the true value and overstating. Non-deviation from a pooling equilibrium is individually rational if:

$$
\left.\mathrm{r}_{\mathrm{E}} \mathrm{b}+\mathrm{p}(0) \mathrm{F}\right)<\mathrm{r}_{\mathrm{E}}\left(\mathrm{b}+\mathrm{a}(\underline{\mathrm{V}}-\bar{V})-+\mathrm{p}\left(\underline{\mathrm{V}}-\mathrm{V}^{\prime}{ }^{\prime}\right) \mathrm{F}\right.
$$

or

$$
\mathrm{a}(\bar{V}-\underline{\mathrm{V}})-\mathrm{p}((\bar{V}+\underline{\mathrm{V}}) / 2) \mathrm{F}+\mathrm{p}(0) \mathrm{F})<0
$$


This is the more likely, the lower is a and the more pronounced the effect on the probability of fundraising in the next period is.

From this theoretical set-up we can derive the following hypotheses:

$>$ Inexperienced VCs have a stronger incentive to come up with high valuations; i.e. the larger the proportion of unexperienced VCs the higher the average degree of overstatement

$>$ Since it takes longer to find out about overvaluations in the early stage period, the costs of overvaluation are lower there, making it more likely there.

The less stringent accounting rules are the more likely is it that higher valuations emerge (the LHS of (B.3) decreases with a).

A smaller investment (e.g. a syndicated one) is less likely to be overstated.

The hypotheses pertaining to the determinants of realized IRRs and the reporting of unrealized IRRs are tested in sections 4 and 5, respectively, with the data described in section 3.

\section{Data}

\subsection{Data Description}

Our dataset was collected by the Center of Private Equity Research (CEPRES), Germany (see also Schmidt, 2003). The data comprise 221 venture capital funds, 72 venture capital firms, 5040 observations for entrepreneurial firms (3826 venture capital and 1214 private equity), 32 years (1971 - 2003), and 39 Countries from North and South America, Europe and Asia. ${ }^{8}$ The data are completely anonymous. For reasons of confidentiality, names of funds, firms etc. are not disclosed.

The CEPRES dataset is somewhat related to other VC and entrepreneurial finance papers with cross-country datasets. The scope of our data is similar to Black and Gilson (1998) and Jeng and Wells (2000), but those datasets are based on aggregate industry figures and comprise no transactionspecific information. Lerner and Schoar (2003) present cross country data on specific transaction

\footnotetext{
Specifically, the countries include Argentina, Austria, Belgium, Brazil, Canada, China, Czech, Denmark, Finland, France, Germany, Greece, Guatemala, Hong Kong, Iceland, India, Indonesia, Ireland, Israel, Italy, Japan, Korea, Luxembourg, Malaysia, Netherlands, Norway, Philippines, Poland, Portugal, Puerto Rico, Romania, Russia, Singapore, Spain, Sweden, Switzerland, Taiwan, the UK, and the USA.
} 
structures with a couple of hundred of observations, but do not have data on returns. Cumming and MacIntosh (2003) have data on exits and returns in Canada and U.S., but are limited in both breadth and depth of transactions. Similarly, Cumming and Fleming (2003) have data on a couple of hundred investments from 13 Asia-Pacific countries, but lack details comprised herein, such as unexited IRRs, etc. Gompers, Lerner and Desai (2003b) present a large dataset on entrepreneurial firms across different European countries, but do not consider information pertaining to venture capital finance.

Our dataset is also somewhat related to U.S. datasets. Schmidt (2003) investigates the risk and return characteristics of private equity fund investment in US portfolio firms. Ljungqvist and Richardson (2003a) and Kaplan and Schoar (2003) present data on private equity returns at the fund level, but do not make use of transaction specific details for each entrepreneurial firm investment. Our paper focuses on the returns to investment in each specific entrepreneurial firm, as in Ljungqvist and Richardson (2003b) and Cochrane (2001). Cochrane (2001) and Ljungqvist and Richardson (2003b) present U.S. data on venture capital and private equity returns. Our dataset is different from Cochrane (2001) in that we have more specific details on each transaction (discussed in detail below), and returns across countries. Our dataset is different from Ljungqvist and Richardson (2003b) and Cochrane (2001) in that we have more specific details on each transaction, and we control for selection effects (as does Cochrane, 2001, but unlike Ljungqvist and Richardson, 2003b).

The data comprise 2498 fully realized investments, 954 partially realized investments, ${ }^{9}$ and 1665 unrealized investments. The data are depicted in Figures 1 and 2. The volume of data (Figure 2 ) is consistent with that reported elsewhere (see, e.g., Gompers and Lerner, 1999, and Lerner, 2002a, for the volume of transactions in the U.S.). The presence of realized, partially realized and unrealized investments (Figure 2) is a useful attribute of the data as it enables us to consider selection effects (in the spirit of Heckman, 1976, 1979) on 2 dimensions: realized versus unrealized, and full versus partial. ${ }^{10}$ In estimating the determinants of returns, we consider selection effects on both dimensions (consistent with Cochrane, 2001, but Cochrane does not have details on partial exits).

[Figures 1 and 2 About Here]

Importantly, our data comprises details on the actual IRRs for realized investments (accounting for all cash flows between the investor and the entrepreneurial firm). This is distinct from

\footnotetext{
A partially realized investment involves a disposition whereby less than $100 \%$ of the investor's ownership interest has been sold (for empirical work on topic, see Gompers and Lerner, 1999; Cumming and MacIntosh, 2003; for theoretical work on topic, see Neus and Walz, 2004). The complete return to the investment cannot be perfectly measured for partial exits our dataset.

10 It would be possible to present selection effects for a third dimension: whether we have a complete set of details for each transaction. That is, we exclude some of the observations in the empirics where we do not have a complete set of details on each variable of interest. This approach is consistent with that advocated in Greene (1997). Cochrane (2001) adopts a similar approach in excluding observations with incomplete data.
} 
other papers (e.g., Cochrane, 2001), who appear to proxy returns based on initial cash flows and final cash flows. Our actual IRRs are not approximations; the data are extremely precise.

Further, our data comprises details on the IRRs of unexited investments; that is, the IRRs reported to institutional investors by the venture capital funds on unexited transactions. These unexited IRRs in the data were reported in the period from June 2000 - Sept. 2003 (and the investment dates are indicated in Figure 2). The presence of unexited reported IRRs is unique and significant, as it enables us to compare these reported unexited returns with the predicted returns for unexited investments (based on our analysis of returns derived from exited investments). No prior paper has data on topic. We believe this dimension of the data and analysis is an important new contribution to the literature, particularly in light of the recent U.S. CALPERS case. ${ }^{11}$

The data comprise very detailed information on a number of different transaction-specific variables, as summarized and defined in Table $1 .{ }^{12}$ The types of variables are broken down into 4 primary categories: market and legal factors (MSCI and risk-free return, and legality, earnings aggressiveness and disclosure level indices), VC fund characteristics (fund number in the VC firm, age of fund, portfolio size per VC manager), entrepreneurial firm characteristics (stage of development, industry, location), and investment characteristics (lead investor, syndication, coinvestment, board seats, convertible securities, and amounts invested). These variables are used in the ensuing empirical analyses.

[Table 1 About Here]

\subsection{Summary Statistics}

Summary statistics are presented in Table 2. The summary statistics are separated into 5 categories: (A) all funds, (B) market and legal factors, (C) VC fund characteristics, (D) entrepreneurial firm characteristics, (E) transaction specific characteristics. Comparison tests are explicitly provided for average and median returns across fully realized versus unrealized (or only partly realized) investments. (Comparison tests across different characteristics within the grouping of realized or unrealized characteristics are apparent, but not explicitly provided from reasons of conciseness.)

[Table 2 About Here]

\footnotetext{
11 The CALPERS case and related issues were discussed in the Introduction.

There are a few additional details in the dataset that are not reported in this paper. The main reasons are that, as per our theoretical model, we believe we have captured the important aspects that pertain to the research questions at hand. Excessive reporting of other variables would detract from the central focus.
} 
The data indicate the median unrealized IRR is 0.00 for all transactions (Table 1, Part A, row 1), but the average unrealized IRR is $63.23 \%$. Realized IRRs, by contrast, have a median of $16.99 \%$ and an average of $68.67 \%$. Median realized IRRs are significantly greater than median unrealized IRRs, but average realized IRRs are not statistically different from one another. The insignificance of the differences in average values is attributable to the very large standard deviations of the returns. The fact that private equity returns have a massive variance has previously been reported with U.S. data (Cochrane, 2001). The dispersion of the returns in our data is graphically depicted in Figure 1.

Some very interesting differences are observed in the data in regards to breakdowns by market and legal factors. When public equity markets experience high returns (Table 2, Part B, row 2), realized returns are greater than unrealized returns; however, when public equity markets experience low returns (Part B, row 3), unrealized returns are greater than realized returns. The same differences are true in regards to risk free returns (Part 3, rows 4 and 5) in hot versus cold market periods. Likewise, note that unexited investment returns are much higher in hot versus cold markets. As well, note that unexited investment returns are sticky downwards at $0.00 \%$. The data clearly indicate private equity and venture capital fund managers tend to not write-down the value of an investment below its book value, until such losses are actually realized.

In regard to the legal and accounting indices (Table 2, Part B, rows 6-11), the average realized IRRs are insignificantly different from the average unrealized IRRs, but the median IRRs are higher for realized investments. It is noteworthy that for unrealized IRRs, the average IRRs are higher among countries with lower legality and accounting indices. Due to the massive variance in IRRs, these difference of means tests are not statistically significant, but nevertheless suggestive of trends in the data that warrant further investigation in the multivariate analyses below.

Part $\mathrm{C}$ of Table 2 reports the data by various $\mathrm{VC}$ fund characteristics. While average and median realized returns are higher among funds within VC firms of different vintage (rows 12 and 13), note that funds in VC firms of younger vintage ( 3 or fewer funds per firm) have much higher median unrealized IRRs. Regarding the age of a particular fund, younger funds (less than 1795 days) are less inclined to report losses on unrealized investments (row 15). It is also noteworthy that funds with large portfolios have statistically significantly higher average unreported IRRs relative to reported IRRs. This latter result is suggestive that funds which add less value to their entrepreneurial firms ${ }^{13}$ are more inclined to exaggerate their IRR performance on unexited investments.

\footnotetext{
13 Portfolio size (in terms of the number of investees) per manager and value-added are inversely (Kanniainen and Keuschnigg, 2003a,b).
} 
Part D of Table 2 reports the data by entrepreneurial firm characteristics. ${ }^{14}$ The data indicate that for the start-up and early stages of investment (rows 19 and 20) (for which informational opaqueness is very pronounced), unrealized IRRs are greater than realized IRRs. (Although for the earliest seed stage, the median unrealized IRR is 0.00 , since it would conceivably be quite difficult to justify very high IRRs for concept firms.) Unrealized IRRs are less than realized IRRs at the latter development stages. It is also noteworthy that firms in industries with high market/book values (among publicly traded companies), the average unrealized IRRs are quite high (more than $100 \%$; but insignificantly different from realized IRRs due to the high variance).

Part E of Table 2 reports the data by investment characteristics. Lead investors (row 30) report very high average IRRs on unrealized investments (more than 75\%). Average unrealized returns among firms for which convertible securities were used, and among firms with high standard deviations of cash flows are also high (more than 100\%). But again these differences are not insignificantly different from realized IRRs due to the high variance).

Table 3 provides a correlation matrix for the full sample of all realized and unrealized investments. The correlations provide some insight into the univariate relations between the variables. For instance, portfolio size is negatively associated with private equity returns and positively associated with public market returns (consistent with theoretical work of Kanniainen and Keuschnigg, 2003a,b); co-investment is (obviously) associated with VC funds in VC firms with more funds; syndication is associated with higher private equity returns; board seats are associated with investment in earlier stage firms. The correlations also indicate potential collinearity problems across the variables to be considered in the multivariate analyses below. ${ }^{15}$

[Table 3 About Here]

Section 4 immediately below provides a multivariate analysis of the determinants of realized returns across countries. Section 5 thereafter considers the difference between unrealized returns as reported to institutional investors and predicted realized returns (for the unrealized investments) based on the models presented in section 4 .

\section{Multivariate Analysis of IRR Performance}

\footnotetext{
Note that across countries the definition of a seed, start-up, early stage and even expansion stage firm is a little difficult due to differences in conventions across countries. For many of the firms in the data we were unable to obtain a reliable definition, and therefore use an 'unknown' category (row 22).

For instance, note that the committed capital variable and the MSCI variable are significantly negatively correlated. For these variables (and others) we checked robustness by including / excluding these variables jointly and separately. The results reported below are very robust. Alternative specifications not explicitly provided are available upon request.
} 


\subsection{Empirical Methods}

Our interest in this section is in studying the determinants of fully realized returns in our cross-country sample described above. There are two approaches that appear to have been employed in prior work. On one hand, one could use OLS on a subsample of the fully realized returns (our understanding is that this is the approach used by Ljungqvist and Richardson, 2003b, Table 6, for a U.S. sample). On the other hand, one could account for sample selection issues in regards to exited and unexited investments (as considered by Cochrane, 2001, for a U.S. sample). In this paper, we use OLS on the subsample of realized returns, and then show the robustness of those results to sample selection corrections.

Our sample selection corrections procedure involves multiple steps. The first step involves determining the probability of an exit (either full or partial). The second step involves determining the probability of a full exit (versus a partial exit, as defined above), taking into account the first step consideration of an actual exit (this Heckman-like methodology is from Wynand and van Praag, 1981). The third step is the linear regression explaining returns with the sample selection correction based on steps one and two (based on Heckman, 1976, 1979). It is noteworthy that our results are quite robust to alternative specifications of the sample selection corrections (alternative specifications not specifically reported are available upon request), but not as robust relative to the standard OLS estimates on the subsample of fully realized exits. Our approach builds on prior work by considering a multi-step Heckman-like sample selection correction on realized/unrealized exits and full/partial exits. This approach is intuitively sensible, and out-performs other single-step sample selection corrections (again, available on request but not explicitly reported), ${ }^{16}$ as well as standard OLS methods on the subsample of realized exits (which is explicitly indicated).

Our econometric specifications are the function of the following variables:

(1) Probability of observing an actual exit $=f$ \{age of investment $\}$

(2) Probability of a full exit $=f$ \{age of investment, legality, stage of investment, country dummy variables, industry dummy variables, exit year dummy variables, syndication | Actual Exit in regression (1)\}

(3) Realized returns $=f$ \{market and legal conditions [MSCI returns, risk-free returns, legality, committed capital in market at investment date], VC fund characteristics [fund number and portfolio size per manager], entrepreneurial firm characteristics [stage of development,

\footnotetext{
16 Ideally, our specifications in each step would involve different explanatory variables (Puhani, 2000). To some extent we are able to achieve this, as the right-hand-side variables do not completely overlap. For instance, the age of the investment is in steps (1) and (2) but not step (3). Our reported results are robust to alternative specifications. A limitation in our dataset is that in many cases the precise exit vehicle (IPO, acquisition, buyback) is unknown, and hence that dimension cannot be explored with the data. Nevertheless, this is not a significant limitation for our research question as there is no causal relation from exit vehicle choice to returns; exit choice would be endogenous to a good project with high returns.
} 
industry market/book, country of residence dummy variables, industry dummy variables, exit year dummy variables], investment characteristics [lead investment, syndicated investment, co-investment, board seats, convertible security, standard deviation of amount invested, and initial amount invested] | Actual Exit [regression (1)] and Full Exit [regression (2)]\}

The particular variables were defined above and summarized in Table 1. Other variables present in the data (such as other measures of market returns, etc.) were considered but deemed less relevant. We present regressions in which the left- and right-hand-side variables are in logs (of course, the dummy variables are not in logs). As such, the coefficients are interpreted as elasticities. We also considered the regressions in levels; those results were very similar, and are available upon request.

There could be a concern that some of the right-hand-side variables are endogenous. For example, syndication might be endogenous if project quality affects the probability of syndication. We did consider this issue, but were limited by the absence of ideal instruments. Some instruments considered included fund characteristics (such as fund location, if different from the entrepreneurial firm, and fund size), which could be more closely connected to syndication than to returns themselves. As we did not find material differences in the eventual results, we have only reported the straight estimates without the use of instrumental variable methods. As other papers in the literature do not use instrumental variables when explaining returns to investment as a function of syndication and other investment characteristics (see, e.g., Brander et al., 2002, on the effect of syndication on returns in Canada), we report specifications without the use of instruments. Regardless, additional specifications are available upon request. Other papers (Cochrane, 2001; Ljungqvist and Richardson, 2003) or do not consider the effect of any investment characteristics on returns. We feel less comfortable with dropping these variables, as they have been used, for example, to explain the performance of venture capital backed IPOs and the ensuing returns to VCs (Barry et al., 1990; Megginson and Weiss, 1991; Gompers and Lerner, 1999). Failure to consider these variables may result in a more serious omitted variables problem relative to any concern with respect to endogeneity.

\subsection{Empirical Results}

We present the results for the subsample of investments in which the first round was in the seed, start-up, early or expansion stages (Table 4 Panel A), as well as the results for the full sample that also comprises the different types of later stage private equity investments (Table 4 Panel B). We point out certain differences in the estimates in the different samples. We explicitly present four models in each Panel. Model (1) is the standard OLS on the subsample of fully realized exits. Model (3) is the three-step bivariate Heckman-corrected estimates based on actual exits / no exit and full exits / partial exits. Models (2) and (4) are the same as models (1) and (3), respectively, with the 
exception that Models (2) and (4) have dummy variables for different industries, different exit years and different countries.

[Table 4 Panels A and B About Here]

It is noteworthy that the data indicate a superior fit in regards to the Heckman corrected Models (3) and (4) relative to the simple OLS Models (1) and (2) on the subsample of realized returns. Adjusted $\mathrm{R}^{2}$ and likelihood ratio, Akaike and other model selection criteria all point to the appropriateness of the Models (3) and (4) (this is the case more so for Panel A on the subsample of earlier stage investments than for Panel B on the full sample including the later stage investments). However, as between Models (3) and (4), there is no clear statistical indication of a preference for one Model or the other.

\section{Selection Effects}

The step 1 selection regressions in Models (3) and (4) indicate exit itself is more likely to be observed in the data the longer the duration of investment. This is an obvious point, and this variable has been used in prior work on topic with a sample of U.S. data (Cochrane, 2001).

The step 2 selection regressions in Models (3) and (4) consider the determinants of full versus partial exits. A partial exit facilitates ownership transfer when it is relatively more difficult for the new owner to value the firm and monitor the investee. Consistent with prior work (Gompers and Lerner, 1999), venture capitalists will choose a partial exit (thereby delaying liquidity) when informational problems faced by the new owners are more pronounced. Our specifications control for industry factors, year effects, stage of development at first investment, investment duration, and investment syndication (consistent with Gompers and Lerner, 1999; see also Cumming and MacIntosh, 2003). The data indicated controls for other factors were not warranted. As well, we did not want to over-specify the full/partial exits regressions as it is undesirable for the different Heckman regressions to have right-hand-side variables that are overly correlated across equations (see, e.g., Puhani, 2000). The data indicate full exits are more likely the longer the investment duration and less likely for syndicated investments. The duration evidence is intuitive, in that a longer investment duration (until the first exit date, not the full exit) facilitates certification of quality vis-à-vis the entrepreneurial firm and its new owners (Megginson and Weiss, 1991). The syndication evidence is less intuitive, as syndication itself could certify quality. Syndication may be a signal of informational problems themselves, and there could be some underlying variable that is driving both the syndication decision and the partial exit which is unobserved. These details are not apparent in our data. The evidence in regards to stage of development is sensitive to the inclusion/exclusion of the dummy 
variables for industries, countries and exit years in model (3) versus model (4). Finally, the Table 4 Panel B indicate that full exits are more likely countries with higher legality indices, which is expected as there is less of a need to certify quality via a partial exit when investors have better legal protections and certainty.

Alternative specifications for the first-step selection regressions were considered (including alternative right-hand-side variables, single-step mechanisms versus multiple step, etc.), but did not materially impact the results presented, nor those discussed below pertaining to IRRs. Different specifications are available upon request. Given these preliminary selection regressions, we now turn to an analysis of the returns based on the Heckman corrections, with comparison to standard OLS regressions on the subsample of fully realized IRRs.

\section{The Impact of Market and Legal Factors on Returns}

The importance of considering selection effects in the data is perhaps best illustrated by the first variable, the log of the MSCI return. In the OLS specifications on the restricted sample (Models (1) and (2)), public market returns are statistically unrelated to exit outcomes. Only in Model (4) do we find a statistically significant and positive coefficient in Panel A, and Models (3) and (4) in Panel $\mathrm{B}$, which is of course expected as per the CAPM. The data indicate that the beta coefficient on the log MSCI index is slightly greater than one. ${ }^{17}$

The coefficient on the legality index is positive and significant in all of the specifications (the one exception is Model (3) in Panel B, where the coefficient was marginally insignificant). This indicates that legal protections facilitate venture capital and private equity returns, consistent with studies of industry-wide private equity profits across countries (Armour and Cumming, 2003), as well as the role of legality on public markets (see La Porta et al., 1997, 1998, and related papers).

The committed capital variable is negative and significant in Models (1) and (2), insignificant in Model (3) and positive and significant in Model (4). A priori, we would expect a negative coefficient if excess capital bids up deal prices and lowers returns (Gompers and Lerner, 2000). The reversal of the sign of this coefficient is likely attributable to the fact that the presence of an exited versus unexited investment is closely connected to the market conditions at the time of investment. Our unexited investments are ones that had not been exited around the period from June 2000 to

17 By contrast, Cochrane (2001) finds the log CAPM market coefficient to be around $90 \%$. Cochrane's data are only from the U.S., which might suggest that VC returns across countries are slightly riskier than in the U.S. However, Cochrane accounts for at most $1 \%$ of the variation of the returns in his sample, while our consideration of other variables enable more than $35 \%$ of the variation in returns to be explained. Further, our sample selection mechanisms are different (e.g., we include a step for full and partial exits, described above). Given the risks and illiquidity in venture capital and private equity, it is natural to expect a beta on the market return variable to be greater than one. 
September 2003. The sample selection corrections on this dataset indicate that the greater capital inflows were associated with higher returns. ${ }^{18}$

\section{The Impact of Fund Characteristics on Returns}

We report results for two primary fund characteristics: the VC fund number in the VC firm (later funds may perform better if they are more experienced), and portfolio size (number of investees) per VC manager. On one hand, we do not find a significant effect of fund number on returns. ${ }^{19}$ On the other hand, the effect of portfolio size per VC manager is highly significant and economically large (consistent with Kanniainen and Keuschnigg, 2003a,b; Keuschnigg, 2003): the estimated elasticity ranges from 0.31 to 0.51 in Table 4 Panel A and from 0.25 to 0.33 in Panel B. The smaller economic effect in Panel B is consistent with the widely held view that venture capital and private equity investment managers add less value to later stage investments relative to earlier stage investments (see Gompers and Lerner, 1999, for the majority of the seminal work on point). Overall, although prior seminal work specifically examining VC returns (e.g., Cochrane, 2001; Ljungqvist and Richardson, 2003b) has not considered the effect of portfolio size, the evidence from this dataset suggests this is quite an important variable. In fact, the advice provided by the investor to the investee is the primary element that distinguishes venture capital and private equity from other forms of financial intermediation (Gompers and Lerner, 1999).

\section{The Impact of Entrepreneurial Firm Characteristics on Returns}

A somewhat surprising result in the data is that the earlier stage investments did not outperform the later stage investments (see also the summary statistics in Table 2). ${ }^{20}$ The earlier stage of investment variables (for stage of investment at first investment) are generally insignificant, or negative and significant (the only exception is in Table 4, Panel A, model 3 for start-ups, but that coefficient estimate is not robust). By contrast, the late stage (pre-IPO; see Panel B in Table 4) yielded higher returns. Similarly, there were a total of 14 realized returns for investments in publicly listed companies in the data, and these outperformed as well (see Table 2, and Table 4 Panel B). ${ }^{21}$ For the most part, the regressions are robust to controls for different country dummy variables, industry dummy variables, and year of exit dummy variables.

\footnotetext{
18 This result is not directly comparable to Gompers and Lerner (2000), since we have a specific dataset where nonrealizations are concentrated in a period after the Internet bubble market crash. As well, we have a multitude of countries in the data. Further, our focus is not on initial valuations of investments, as considered by Gompers and Lerner (2000); rather, our focus is on returns. As indicated supra note 15, note that the coefficient on committed capital is not affected by collinearity with the MSCI variable.

19 By contrast, Schmidt et al. (2003) find a significant influence of fund number on performance at the fund level.

A similar finding is reported in Schmidt (2003) in his portfolio approach.

These investments actually appear to be IPO allocations in which investment banks enabled the VC fund to buy in to a publicly listed company early on to take advantage of IPO underpricing.
} 
The Impact of Investment Characteristics on Returns

Investment structures appear to have a significant effect on returns in a number of different dimensions. First, syndication significantly enhances returns, consistent with the view that syndication facilitates value-added (Lerner, 1994; Brander et al., 2002). Second, co-investment and board seats are associated with lower returns. One explanation for this result is that co-investment and board seats are more likely for poorly performing investments, as indicated by Lerner (1995) and Gompers and Lerner $(1996,1999){ }^{22}$ Third, convertible securities with periodic cash flows (Table 1) enhance returns, consistent with the view that convertibles give rise to incentives for the investor to provide value-added advice and efficiently monitor, and incentives for the investee to work (for recent theoretical work, see, Casamatta, 2003; Schmidt, 2003). Convertibles also facilitate efficient exit (Bascha and Walz, 2001a), which is consistent with the higher returns associated with convertibles.

Consistent with the evidence discussed above pertaining to the stage of investment, the evidence on the size of the initial investment indicates lower returns to smaller investments (but this effect is statistically significant in Panel A only). As regards to the economic significance, the estimated elasticity is approximately 0.10 in Panel A, which is statistically significant only when selection effects are considered.

The standard deviation of the cash flows (normalized by initial investment amounts; Table 1) is positively associated with returns. Variability in the size of cash flows is a direct proxy for the risk of the investment, so we would expect a positive coefficient in that riskier investments are associated with greater returns. This positive association is stronger and more robust for the subsample of earlier stage investments (Panel A) relative to the full sample of all investments (Panel B).

\section{The Impact of Selection Effects on Realized Returns}

It is important to point out that both selection effects have a statistically and economically important impact on the measurement of returns. The Lambda A and B coefficients are both negative and statistically significant in Models 3 and 4 in Table 4 Panels A and B (with the exception of Model 3 in Panel A, where Lambda B is marginally insignificant). The negative sign of these coefficients indicates realized returns are systematically lower than realized returns. In particular, unrealized returns from no exit are roughly 7-9\% higher than realized returns, and unrealized returns from partial

\footnotetext{
22 As indicated above, this may indicate these variables are endogenous. Alternative specifications with instruments did not materially affect the results, as discussed above. As well, specifications in which this (and related investmentspecific) variables were dropped altogether did not materially affect the results pertaining to the other variables reported in the tables.
} 
exits are roughly $1-2 \%$ higher than realized returns. This implies that the degree to which unexited returns are overstated is greater for completely unrealized exits relative to partly realized exits. Our examination of completely unrealized exits is therefore the focus of our analysis in the next section.

In order verify the correctness and importance of selection effects, one particularly suggestive exercise in this respect was to run an OLS regression (not reported in the Tables) with the IRRs of our entire sample as the LHS variable. Using our variables from above and adding a dummy for the unexited investments reveals a highly significant (t-statistic of 14.979, significant at the one percent level) positive coefficient (equal to 2.049) for the unexited dummy variable. We interpret this as a strong indication of overreporting. In the next section we investigate the determinants of the differences between reported and predicted valuation of unexited investments.

Overall, the models in Table 4 Panels A and B provide quite a strong fit to the data. Adjusted $\mathrm{R}^{2}$ values are quite high (ranging from $26 \%$ to $36 \%$ ). By contrast, other approaches to measuring returns with U.S. VC data which do not consider selection effects account for up to $13 \%$ of the variation in returns (Ljungqvist and Richardson, 2003b), and papers which do not account for VC value-added activities and transaction specific details account for only $1 \%$ of the variation in returns (Cochrane, 2001). The high $\mathrm{R}^{2}$ values in our specifications are useful for reliably predicting returns to unrealized investments, as considered in the next section.

\section{Analysis of Disclosure}

In this section we make use of the estimated coefficients in each of the 4 models presented in Panels A and B of Table 4 in order to study the difference between predicted IRRs on unrealized investments and unrealized IRRs reported to the institutional investors that contributed capital to the VC funds. As indicated in subsection 2.2, our prior is to expect systematic reporting biases where there is greater informational asymmetry associated with the entrepreneurial firm, the VC fund, and the market and legal environment.

The regression results on the difference between the determinants of the differences between reported and predicted valuation of unexited investments are reported in Table 5 (Panels A and B). The dependent variables are measured as the actual reported unexited IRR to the institutional investors less the predicted IRR (based on the table 4 results) for the particular investment. These differenced amounts are expressed as $\log (1+$ Reported IRR $)-\log (1+$ Predicted IRR $)$, which could alternatively be interpreted as $\log ((1+$ Reported IRR $) /(1+$ Predicted IRR $))$, so that the economic significance of the coefficients directly indicate the relative degree of overstatement. 
The models variables exclude partial exits, as the returns for those investments are factual (albeit, not observed in full, by definition, and hence the selection regressions in the prior section). The dependent variables for each model in Table 5 correspond to the model numbers presented in Table 4. We report two different specifications for each of the Table 4 models: the models with subscript ' $a$ ' comprise a few explanatory variables; the models with subscript ' $b$ ' comprise a complete set of explanatory variables. As above, the variables are defined in Table 1.

[Table 5 Panels A and B Here]

The data are strongly consistent with the prediction that valuations of unexited investments are higher when information asymmetries faced by institutional investors is more pronounced. In particular, there valuations reported by younger VCs are significantly higher. This can be attributed to the fact that older VC funds have more reputational capital at stake whereas younger funds have an incentive to signal with higher valuations thereby increasing the probability of closing the next fund. ${ }^{23}$ There is more overreporting among funds with larger portfolios per general partner, among early and expansion stage investee firms, firms in high market/book industries and certain industries in particular (e.g., Internet) (consistent with, and among smaller investments. The results pertaining to portfolio size are consistent with theoretical work of Kanniainen and Keuschnigg (2003a,b) in that funds with larger portfolios add less value to their investees and tend to be less profitable (see section 4), and therefore have a greater incentive to overstate. The findings pertaining to stage of development and industry factors are consistent with Gompers (1995) and Gompers and Lerner (1999) in those investments are ones for which informational asymmetries are more pronounced, and therefore there exists greater scope for exaggerating unexited returns.

One surprising finding is the result that there is more overreporting when VCs have a seat on the board of directors of the entrepreneurial firm. We may have expected the exact opposite, as VCs gather more information about the investee by sitting on the board of directors (Lerner, 1995; Gompers and Lerner, 1999). Our data are suggestive that sitting on the entrepreneur's board does not mean that VCs will be more inclined to 'tell the truth' about the value of the company when reporting to their institutional investors.

The data indicate less overreporting among syndicated investments and when the VC holds a convertible security that provides periodic cash flows. These two results are intuitive and in line with our theoretical reasoning. First, investors are less inclined to report high valuations when their actions might be monitored (and therefore potentially revealed) by other syndicated investors. The benefits of

23 This is in line with the findings of Gompers and Lerner (1996, 1999) and Schmidt and Wahrenburg (2003) who provide empirical evidence that reputation (and the resulting bargaining power) drives the use of covenants between VC fund and investor. 
overstating are reduced whereas the costs increase. Second, regarding convertibles, Brennan and Kraus (1987) show that convertibles facilitate valuations that are more robust to errors in the fundamental value of the firm.

Note that there is more overreporting in conditions of weak public markets (low MSCI indices and higher returns on debt markets (substitute markets for institutional investors to place their funds). VCs appear loathe to write down the book value of the investees. As indicated in Table 2 and Figure 1, unexited returns are rarely less than $0.00 \%$.

The sensitivity of the over-valuations to legal and accounting indices is extremely interesting. Our results indicate that valuations are overstated by VCs in countries with worse legality indices, worse disclosure indices, and in countries with higher earnings aggressiveness indices. ${ }^{24}$ As such, there is a strong role for the legal and accounting environment in curbing overstatement of unexited venture capital and private equity returns. This result has not only strong implications and feedbacks for the VC industry per se (and the venture capital funds therein) but also for the political agenda. Our results indicate that it is the interest of experienced and established players in the venture capital industry (and potentially for the industry as a whole) to have stringent accounting rules. More stringent accounting rules reduce significantly the incentives (and possibilities) to "lie". This, in turn, makes the valuations more informative, thereby benefiting the entire industry as a whole. In a sense, it avoids a "negative equilibrium" with overreporting. The same rationale implies that policy makers should takes this effects into account and provide a coherent legal environment for the VC industry as well as enforce rather tough accounting rules in order to improve the communication between VCs and investors which then is most likely to lead to more capital flowing into the industry and thereby into young, innovative firms.

\section{Limitations, Alternative Explanations and Future Research}

We consider our analysis to be a sound step towards understanding the driving forces behind the returns of $\mathrm{VC}$ investments and regard it as a first contribution to the analysis of (over-)reporting of unexited investments. Due to the structure of our data set, there are some limitations of our analysis as well as scope for future research along these lines. First, some of unexplained variance of our IRR measure is without doubt due to deal specific characteristics in the relationship between the venture

\footnotetext{
24 Note that the legal indices are all expressed in logs, with the exception of the earnings aggressiveness index. The reason for this is as follows. The values in this index are small, typically negative, fractions (see Bhattacharya et al., 2003, Table 1). We considered converting into logs (with arbitrary rescaling to make possible a $\log$ transformation). The estimates in logs (available upon request) yielded very similar results without qualitative differences in interpretation of any of the results.
} 
capitalists and their portfolio firms. Since this would, however, require very detailed data this is beyond the scope of the present analysis.

Second, one might argue that some of our RHS variables (such as syndication) might be endogenous. A potential cure of this, such as an instrumental variable approach, is, however hampered by the fact that we do not have any exogenous instruments which are uncorrelated with the IRRs but correlated with the potentially endogenous variables. Since we are, however, also interested in the effect of the investment characteristics on VC's returns per se, we do not consider this to be such a problematic issue. We do not drop these variables, as they have been used, for example, to explain the performance of venture capital backed IPOs and the ensuing returns to VCs (Barry et al., 1990; Megginson and Weiss, 1991; Gompers and Lerner, 1999). Failure to consider these variables may result in a more serious omitted variables problem relative to any concern with respect to endogeneity.

Third, we did not differentiate among the different exit channels chosen. This is due to the fact that our information on exit channels chosen is not very complete. In some cases we know the exit channels, but in other cases further information is missing. In addition, there is only information on two exit channels: trade sales and IPOs. With the partial set of information available for those variables, we did not find selection effects to materially give rise to biases in our reported results.

Furthermore, there are at least two potential routes of future research which are rather straightforward. First, it would of interest to investigate the impact of overreporting of unexited IRRs on subsequent fundraising. With our data we do know there is a positive correlation between fund size and overreporting, but this does not imply causality as the fundraising is not in regards to the funds raised subsequent to the overreporting. This dimension could be considered alongside other factors that affect fundraising (Gompers and Lerner, 1998, Lerner and Schoar, 2002b, Kaplan and Schoar, 2003, Ljungqvist and Richardson, 2003a,b, and Cumming et al., 2004) in future work.

Second, it would be very interesting to track actual ultimate performance to reported performance as at today. This would allow us to look into the overvaluation issue more deeply by not only comparing predicted with reported valuation but by looking at the actual developments of the reported valuation. Given the structure of our dataset, as it stands now, this is not possible with the present dataset, but something that would be useful to do and which might be even feasible with future valuation at the time of exit of the by now unexited investment being included into our dataset in the future. 


\section{Concluding Remarks}

By using a unique data set on the performance of venture capitalist investment in their portfolio companies around the world, we investigated the determinants of IRRs of exited investment as well as the relative valuations of unexited investments as reported to potential investors. Due to the availability of cashflow series for each investment of the respective venture capitalist we were able to calculate the profitability of the investment on the basis of the entire cashflow series. We did not have to rely on a return proxy based on the first inflow and last cash outflow. The cashflow data further indicate functional characteristics of securities that provide periodic cash flows and upside potential, and this makes a significant difference to measuring returns as well as the degree of overstatement of unexited returns. In short, the richness of our dataset enables us to account for different entrepreneurial firm and characteristics, as well as differences in transaction structures. The global nature of the dataset makes it possible to investigate potentially important aspects of economic and financial set-ups, rules and institutions and their impact on $\mathrm{VC}$ returns and reporting behaviour.

Since our data sample comprises a rather long period of time (1971-2003) we are able to avoid a too strong focus of the recent boom and bust years but are able to derive a broader picture. The volume of data at different points in time is consistent with the overall market and its development over time and across the different countries.

Our empirical approach makes use of Heckman selection procedures to correct for potential selection biases in our IRR data of exited investments. We are able to explain a high degree (up to $36 \%$ ) of the total variation in the IRR among the different observations. Prior papers on topic have accounted for between $1 \%$ and $13 \%$ of the variation in returns to U.S. VC investments. Our data indicate an importance in accounting for selection effects in realized versus unrealized returns, as well as for full versus partial exits.

Our main empirical findings mostly support our theoretical considerations. Most importantly we find with respect to the realized IRRs that more monitoring, advice and the use of incentivecompatible financial instruments (convertibles) contribute to a significant increase of the IRRs of realized returns. These findings, as well as the positive impact of the legality index are robust across our different modelling specifications.

To the best of our knowledge we are the first looking at the valuation behaviour of VCs with respect to their unexited investments. Not least to recent industry developments this is an important issue with immediate policy implications. Our empirical analysis supports our theoretical prior here as well. The main findings are that especially young VCs as well as those one being engaged in early 
stage investments are more eager to overreport. In contrast, syndication proves to lower the incentives of VCs to overstate the value of their unexited investments. More importantly, from our point of view, is the very robust significant impact of accounting standards and legal framework on the reporting behaviour of VCs. Less stringent accounting rules and weak legal systems clearly seem to facilitate overvaluation thereby decreasing the informativeness of these valuations. There are two implications. The first one concerns the implication on policy making and the behaviour of the VC industry as a whole. More stringent accounting standards are in the interest of institutional investors, venture capitalists and the economy as a whole (inducing the provision of more risk capital if the information between investors and VCs is less distorted). The second issue is to what extent the overreporting strategy is successful with respect to fundraising, and therefore distorts the allocation of capital across $\mathrm{VC}$ funds and across countries. The relation between overvaluation and future fundraising is a very important question in the venture capital cycle. Future research on topic is warranted.

\section{References}

Armour, J., and D.J. Cumming, 2003. The legal road to replicating Silicon Valley. Working Paper, University of Cambridge Judge Institute of Management.

Barry, C.B.; Muscarella, C.J., Peavy, J.W. III; and Vetsuypens, M.R., 1990. The role of venture capitalists in the creation of public companies: evidence from the going public process, Journal of Financial Economics 27, 447-471.

Bascha, A., and U. Walz 2001a. Convertible securities and optimal exit decisions in venture capital finance, Journal of Corporate Finance 7, 285-306.

Bascha, A., and U. Walz, 2001b. Financing practices in the German venture capital industry: an empirical assessment. Working Paper, University of Frankfurt, Center for Financial Studies.

Berkowitz, D., K. Pistor, and J.F. Richard, 2003. Economic development, legality, and the transplant effect, European Economic Review 47, 165-195.

Bhattacharya, U., H. Daouk and M. Welker, 2003. The world price of earnings opacity. The Accounting Review, forthcoming.

Black, B.S., and R.J. Gilson, 1998. Venture capital and the structure of capital markets: banks versus stock markets. Journal of Financial Economics 47, 243-277.

Brander, J.A., R. Amit, and W. Antweiler, 2002. Venture capital syndication: improved venture selection versus the value-added hypothesis. Journal of Economics and Management Strategy $11,423-452$.

Brennan, M.J., and A. Kraus, 1987. Efficient financing under asymmetric information. Journal of Finance 42, 1225-1243.

Casamatta, C., 2003. Financing and advising: optimal financial contracts with venture capitalists. Journal of Finance 58, 2059 - 2086.

Cochrane, J., 2001. The risk and return to venture capital. Working Paper, University of Chicago Graduate School of Business. 
Cumming, D.J., and J.G. MacIntosh, 2003. A cross-country comparison of full and partial venture capital exits. Journal of Banking and Finance 27, 511-548.

Cumming, D.J., G. Fleming, 2003. The impact of legality on private equity markets: evidence from the Asia-Pacific. Working paper, University of Alberta and Australian National University.

Cumming, D.J., G. Fleming and J. Suchard, 2004. Venture capitalist value-added activities, fundraising and drawdowns. Journal of Banking and Finance, forthcoming.

Gompers, P.A., 1995. Optimal investment, monitoring, and the staging of venture capital, Journal of Finance 50, 1461-89.

Gompers, P.A., 1997. Ownership and control in entrepreneurial firms: an examination of convertible securities in venture capital investments, Harvard Business School Working Paper.

Gompers, P.A., 1998. Venture capital growing pains: should the market diet? Journal of Banking and Finance 22, 1089-1102.

Gompers, P.A. and J Lerner, 1996. The use of covenants: an empirical analysis of venture capital partnership agreements. Journal of Law \& Economics 39, 463-498.

Gompers, P.A., and J. Lerner, 1998. What drives venture fundraising? Brookings Proceedings on Economic Activity - Microeconomics, 149-192.

Gompers, P.A. and J. Lerner, 1999. The Venture Capital Cycle. Cambridge: MIT Press.

Gompers, P.A., and J. Lerner, 2000. Money chasing deals?: The impact of fund inflows on the valuation of private equity investments. Journal of Financial Economics, 55, 281-325.

Gompers, P.A. and J. Lerner, 2001. The venture capital revolution, Journal of Economic Perspectives $15,145-168$.

Gompers, P., J. Lerner and D. Scharfstein, 2003a. Entrepreneurial spawning: public corporations and the genesis of new ventures, 1986-1999. Working Paper, Harvard Business School.

Gompers, P., J. Lerner and M. Desai, 2003b. The two faces of entrepreneurship: evidence from Eastern and Western Europe. Working Paper, Harvard Business School.

Heckman, J., 1976. The common structure of statistical models of truncation, sample selection, and limited dependent variables and a simple estimator for such models. Annals of Economic and Social Measurement 5, 475-492.

Heckman, J., 1979. Sample selection bias as a specification error. Econometrica 47, 153-161.

Hege, U., F. Palomino and A. Schwienbacher, 2003. Determinants of venture capital performance: Europe and the United States. Working Paper, HEC School of Management.

Inderst, R., and H. Mueller, 2003. The effect of capital market characteristics on the value of start-up firms. Journal of Financial Economics, forthcoming.

Jeng, L.A., and P.C. Wells, 2000. The determinants of venture capital funding: evidence across countries. Journal of Corporate Finance, 6, 241-289. 
Kanniainen, V., and C. Keuschnigg, 2003a. The optimal portfolio of start-up firms in venture capital finance. Journal of Corporate Finance 9, 521-534.

Kanniainen, V., and C. Keuschnigg, 2003b. Start-up investment with scarce venture capital support. Journal of Banking and Finance, forthcoming.

Kaplan, S.N., and A. Schoar, 2003. Private equity returns: persistence and capital flows. Working Paper, University of Chicago.

Keuschnigg, C., 2002. Taxation of a venture capitalist with a portfolio of firms. Oxford Economic Papers, forthcoming.

Keuschnigg, C., 2003. Optimal public policy for venture capital backed innovation. CEPR Working Paper No. 3850.

Keuschnigg, C., and S.B. Nielsen, 2001. Public policy for venture capital. International Tax and Public Finance 8, 557-572.

Keuschnigg, C., and S.B. Nielsen, 2003a. Tax policy, venture capital and entrepreneurship. Journal of Public Economics, 87, 175-203.

Keuschnigg, C., and S.B. Nielsen, 2003b. Start-ups, venture capitalists and the capital gains tax. Journal of Public Economics, forthcoming.

Kortum, S., and J. Lerner, 2000. Assessing the contribution of venture capital to innovation. RAND Journal of Economics 31, 647-692.

La Porta, R., F. Lopes-de-Silanes, A. Shleifer, and R.W. Vishny, 1997. Legal determinants of external finance. Journal of Finance 52, 1131-1150.

La Porta, R., F. Lopez-De-Silanes, A. Shleifer and R. Vishny, 1998. Law and finance. Journal of Political Economy 106, 1113-1155.

Lerner, J., 1994. Venture capitalists and the decision to go public. Journal of Financial Economics 35, 293-316.

Lerner, J., 1995. Venture capitalists and the oversight of private firms. Journal of Finance 50, 301-318.

Lerner, J., 1999. The government as venture capitalist: the long-run effects of the SBIR Program. Journal of Business, 72, 285-318.

Lerner, J., 2002a. Boom and bust in the venture capital industry and the impact on innovation. Federal Reserve Bank of Atlanta Economic Review 2002(4), 25-39.

Lerner, J., 2002b. When bureaucrats meet entrepreneurs: the design of effective 'public venture capital' programmes. Economic Journal 112, F73-F84.

Lerner, J., H. Shane, and A. Tsai, 2002. Do equity financing cycles matter? Evidence from biotechnology alliances. Journal of Financial Economics, forthcoming.

Lerner, J. and A. Schoar, 2002b. The illiquidity puzzle: theory and evidence from private equity, Journal of Financial Economics, forthcoming. 
Lerner, J. and A. Schoar, 2003. Private equity in the developing world: the determinants of transaction structure. Working Paper, Harvard Business School and Massachusetts Institute of Technology.

Ljungqvist, A.P., and M.P. Richardson, 2003a. The investment behavior of private equity fund managers. Working Paper, Stern School of Business, New York University.

Ljungqvist, A.P., and M.P. Richardson, 2003b. The cash flow, return and risk characteristics of private equity. Working paper, New York University.

Mayer, C., 2001. Institutional Investment and Private Equity in the UK. Paper produced for conference on 'Corporate Governance: Reassessing Ownership and Control' at Cambridge University, May 2001.

Megginson, W.L., and Weiss, K.A., 1991. Venture capitalist certification in initial public offerings, Journal of Finance 46, 879-903.

Moskowitz, T., and A. Vissing-Jorgensen, 2002. The returns to entrepreneurial investment: a private equity premium puzzle? American Economic Review 92, 745-778.

Neus, W., and U. Walz, 2004. Exit timing of venture capitalists in the course of an initial public offering. Journal of Financial Intermediation, forthcoming.

Puhani, P.A., 2000. The Heckman correction for sample selection and its critique, Journal of Economic Surveys 14, 53-68.

Sahlman, W.A., 1990. The structure and governance of venture capital organizations. Journal of Financial Economics 27, 473-521.

Schmidt, K.M., 2003. Convertible securities and venture capital finance. Journal of Finance 58, 11391166.

Schmidt, D., 2003. Private equity-, stock- and mixed asset-portfolios: A bootstrap approach to determining performance characteristics, diversification benefits and optimal portfolio allocations, Working Paper, University of Frankfurt.

Schmidt, D. , Nowak, E. and Knigge, A. 2003. On the performance of private equity investments: does market timing matter? Working Paper University of Frankfurt and University of Lugano

Schmidt, D. , and M. Wahrenburg, M., 2003. Contractual relations between European VC Funds and investors: The impact of bargaining power and reputation on contractual design. CFS Working Paper, No. 2003/15.

Wynand, P., and B. van Praag 1981. The demand for deductibles in private health insurance. Journal of Econometrics 17, 229-252. 
Figure 1. Histograms of Fully Realized, Partially Realized and Unrealized IRRs

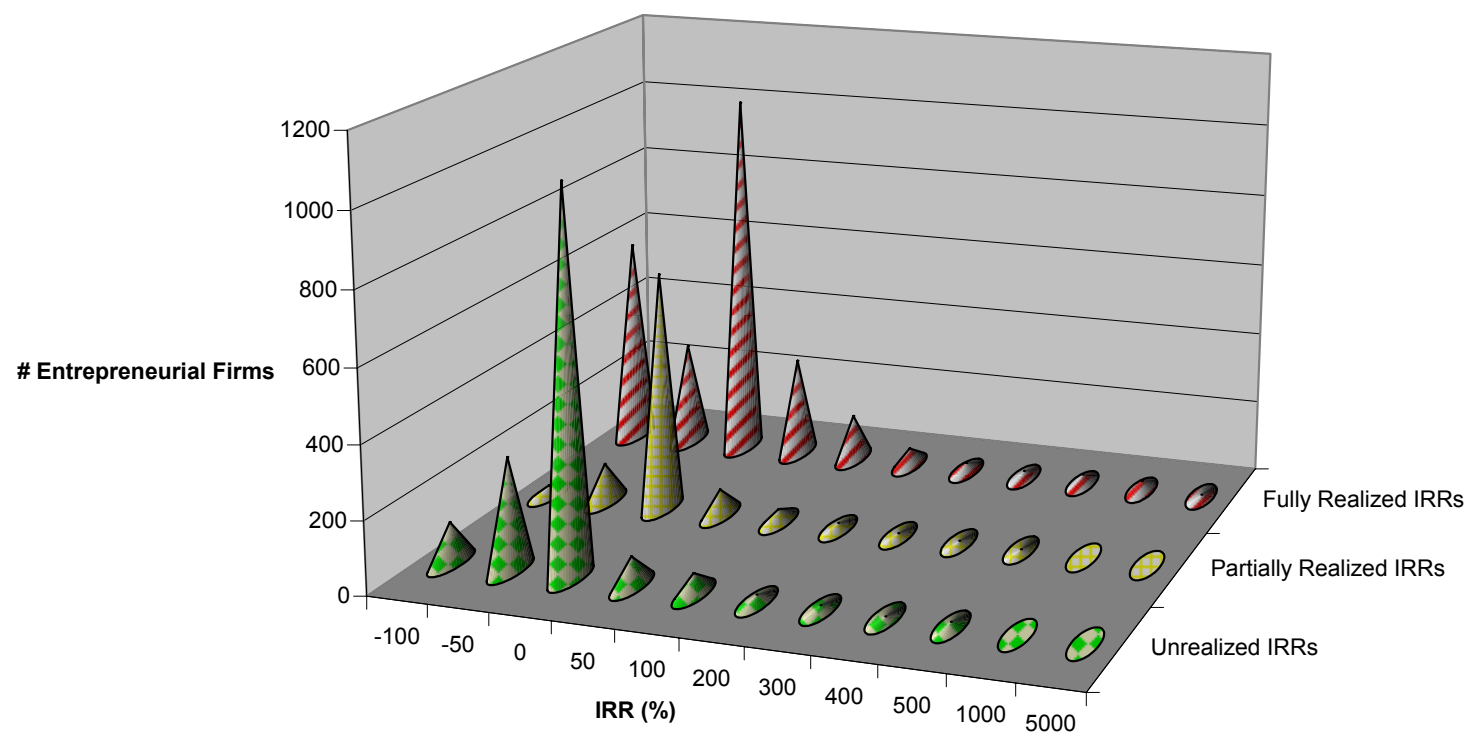

Figure 2. Number of Investments by Year

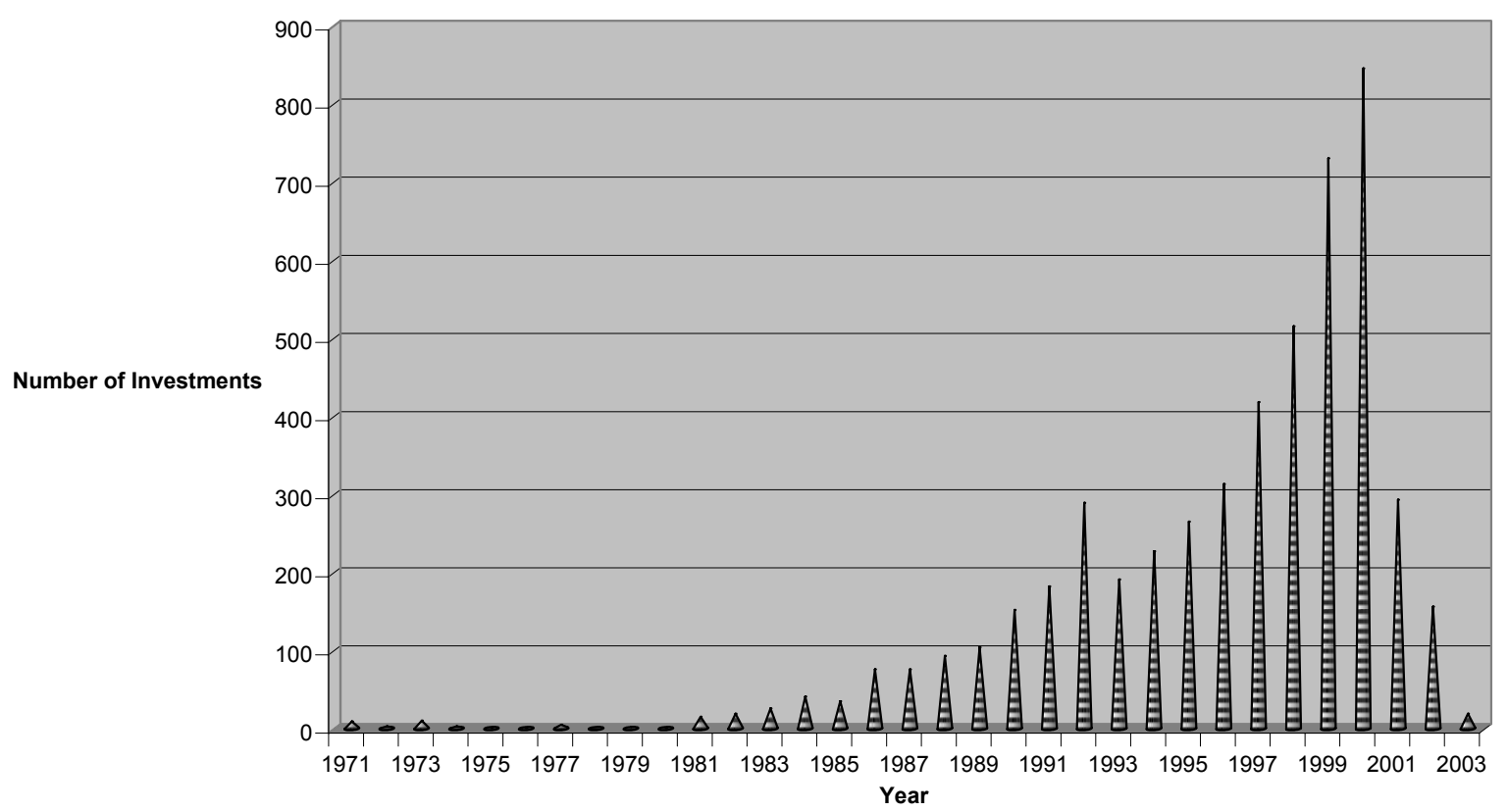


Table 1. Definition of Variables

This table defines the variables considered in this paper. Summary statistics are presented in Tables 2 and 3.

Variable

Internal Rate of Return (IRR)

Market and Legal Factors

MSCI Return

Risk Free Return

Committed Capital Overall Market at Date of Investment

Legality Index

Country Earnings Aggressiveness Index

Country Disclosure Level Index

\section{VC Fund Characteristics}

Fund Number in the VC Firm

Age of Specific VC Fund

Portfolio Size (\# Investees) / \#

General Partners

Entrepreneurial Firm Characteristics

\section{Seed Stage}

Start-up Stage

Early Stage

Expansion Stage

Late Stage

$\mathrm{MBO} / \mathrm{MBI}$

LBO

Publicly Listed Company

Industry Market / Book

Industry Dummy Variables

Country Dummy Variables

Year of Exit Dummy Variables

Investment Characteristics

Lead Investment

Syndicated Investment

Co-Investment

VC Board Seat(s)

Convertible Security with Actual Periodic Cash Flows

Standard Deviation of Cash Flows to Entrepreneur / Initial \$ Invested Initial Amount Invested

Description

The exact IRR based on all actual discounted cashflows

(for unrealized investments the reported valuation is used as the last cashflow).

The country-specific $\mathrm{MSCl}$ return over the contemporaneous investment period.

The U.S. risk-free return over the contemporaneous investment period. (Euro and other risk-free returns were also considered but did not materially change the results.)

The industry total committed venture capital in the overall market (within the particular country) at the date of investment.

Weighted average of following factors (based on Berkowitz et al., 2003): civil versus common law systems, efficiency of judicial system, rule of law, corruption, risk of expropriation, risk of contract repudiation, shareholder rights (as per La Porta et al., 1997. 1998). Higher numbers indicate 'better' legal systems.

Bhattacharya et al.'s (2003, Table 1) measure of firms and accountants tendency in a nation to incorporate economic gains in a more timely fashion than economic losses (i.e., the opposite of accounting conservatism). Higher numbers indicate more aggressive earnings reporting (i.e., less conservative accounting practices).

Bhattacharya et al.'s (2003, Table 1) accounting disclosure measures per country. The higher the number, the better the disclosure.

The number of VC funds the VC firm had operated prior to this current fund.

The age (in days) of the VC fund.

The number of investee companies in the VC fund / the number of general partners in the fund.

A dummy variable equal to 1 for financing provided to research, assess and develop an initial concept before a business has reached the start-up phase.

A dummy variable equal to 1 for financing provided to companies for initial product development and marketing. Companies may be in the process of being set up or may have been in business for a short time, but have not sold their product commercially.

A dummy variable equal to 1 for financing provided to companies with product in testing and/or pilot production. The company may or may not be generating revenue, and has usually been in business less than 30 months.

A dummy variable equal to 1 for financing provided to companies in need of development capital. The financing is provided for the growth and expansion of a company, which may or may not break even or trade profitably. Capital may be used to: finance increased production capacity; market or product development; provide additional working capital.

A dummy variable equal to 1 if the company has reached profitable operating levels.

A dummy variable equal to 1 for buyout financing either of $\mathrm{MBO}$ or $\mathrm{MBI}$ form. MBO: A buyout in which external managers take over the company. Financing is provided to enable a manager or group of managers from outside the target company to buy into the company with the support of private equity investors. MBI: A buyout in which the target's management team acquires an existing product line or business from the vendor with the support of private equity investors.

A dummy variable equal to 1 for a buyout in which the new company's capital structure incorporates a particularly high level of debt, much of which is normally secured against the company's assets.

A dummy variable equal to 1 for companies with a listing on a stock exchange.

The industry market/book ratio for the company's primary industry.

Dummy variables equal to 1 for the company's primary industry.

Dummy variables equal to 1 for the company's country of primary residence.

Dummy variables equal to 1 for the year of exit.

A dummy variable equal to 1 if the investor was the lead investor, 0 if not the lead investor, and 0.5 if unknown.

A dummy variable equal to 1 if the investment was syndicated, 0 if not syndicated, and 0.5 if unknown.

A dummy variable equal to 1 if the investment was co-invested ( 2 or more VC funds in the same VC firm investing in the same entrepreneurial firm), 0 if not a co-investment, and 0.5 if unknown.

A dummy variable equal to 1 if the investor had board seat(s), 0 if no board seats, and 0.5 if unknown.

A dummy variable equal to 1 if the investor held a convertible security which functionally provided for periodic cash flows back to the investor prior to exit.

The standard deviation of the cash flows provided to the entrepreneur from the investor, scaled by (divided by) the initial investment amount.

The initial investment value (in real 2003 U.S. dollars). 


\section{Table 2. Summary Statistics}

This table presents summary statistics by various characteristics of the venture capital funds by $(A)$ all entrepreneurial firms in the dataset, (B) market and legal factors, (C) VC fund chcracteristics, (D) entrepreneurial firm characteristics, (E) transaction-specific characteristics. Summary data for the average and median internal rates of return for number of realized and unrealized transactions are presented. The unit of observation is the entrepreneurial firm ("Ent Firm"). Some observations excluded where information set not $100 \%$ complete for the firm. Difference tests: *, **, ${ }^{* * \star}$ Significant at the $10 \%, 5 \%$ and $1 \%$ levels, respectively. Dollar values expressed in real 2003 U.S. dollars. Variables are as defined in Table 1.

\begin{tabular}{|c|c|c|c|c|c|c|c|c|c|}
\hline \multirow{2}{*}{\multicolumn{2}{|c|}{ VC Fund Characteristics }} & \multicolumn{3}{|c|}{$\begin{array}{l}\text { Unrealized / Partly Realized } \\
\text { Ent Firm Investments }\end{array}$} & \multicolumn{3}{|c|}{$\begin{array}{l}\text { Fully Realized Ent Firm } \\
\text { Investments }\end{array}$} & \multicolumn{2}{|c|}{ Difference Tests } \\
\hline & & $\begin{array}{l}\text { \# Ent } \\
\text { Firms }\end{array}$ & $\begin{array}{l}\text { Average } \\
\text { IRR }\end{array}$ & $\begin{array}{l}\text { Median } \\
\text { IRR }\end{array}$ & $\begin{array}{l}\text { \# Ent } \\
\text { Firms }\end{array}$ & $\begin{array}{l}\text { Average } \\
\text { IRR }\end{array}$ & $\begin{array}{l}\text { Median } \\
\text { IRR }\end{array}$ & Means & Medians \\
\hline 1 & All Funds in the Data & 2619 & 63.23 & 0.00 & 2419 & 68.67 & 16.99 & 0.22 & $\mathrm{p}<=5.96 \mathrm{e}-33^{* * *}$ \\
\hline Part B & Market and Legal Factors & & & & & & & & \\
\hline 4 & Risk Free Return $>3.5 \%$ & 2333 & 49.36 & 0.04 & 2021 & 79.59 & 17.41 & 1.36 & $\mathrm{p}<=2.14 \mathrm{e}-25 * * *$ \\
\hline 5 & Risk Free Return $<3.5 \%$ & 311 & 213.32 & 0.00 & 411 & 12.92 & 15.74 & -1.32 & $\mathrm{p}<=2.54 \mathrm{e}-10$ *** \\
\hline 6 & Legality Index > 20 & 1874 & 60.01 & 2.16 & 1631 & 47.23 & 19.26 & -0.87 & $\mathrm{p}<=7.43 \mathrm{e}-24^{* * *}$ \\
\hline 7 & Legality Index $<20$ & 747 & 71.30 & 0.00 & 788 & 113.04 & 14.21 & 0.54 & $\mathrm{p}<=1.53 \mathrm{e}-12$ *** \\
\hline 8 & Country Earnings Aggressiveness Index $>-0.383$ & 765 & 27.43 & 3.17 & 646 & 85.50 & 18.39 & 1.03 & $\mathrm{p}<=3.15 \mathrm{e}-21 * * *$ \\
\hline 9 & Country Earnings Aggressiveness Index $<-0.383$ & 1858 & 77.92 & 0.00 & 1773 & 62.54 & 16.22 & -0.54 & $\mathrm{p}<=5.07 \mathrm{e}-18 * * *$ \\
\hline Part C & VC Fund Characteristics & & & & & & & & \\
\hline 12 & Fund Number in the VC Firm $>3$ & 1603 & 69.37 & 0.00 & 781 & 88.72 & 1.51 & 0.34 & $\mathrm{p}<=4.05 \mathrm{e}-36 * * *$ \\
\hline 13 & Fund Number in the VC Firm $<3$ & 1018 & 53.55 & 10.30 & 1638 & 59.11 & 20.27 & 0.29 & $\mathrm{p}<=2.59 \mathrm{e}-19$ *** \\
\hline 14 & Age of Specific VC Fund $>1795$ days & 1230 & 54.15 & 9.23 & 2233 & 57.48 & 18.73 & 0.19 & $\mathrm{p}<=2.93 \mathrm{e}-18 * * *$ \\
\hline 15 & Age of Specific VC Fund $<1795$ days & 1391 & 71.25 & 0.00 & 186 & 202.96 & -91.74 & 0.67 & $\mathrm{p}<=1.18 \mathrm{e}-35$ *** \\
\hline 16 & Portfolio Size (\# Investees) / \# General Partners > 20 & 1035 & 59.58 & 0.00 & 988 & 21.29 & 12.34 & $-2.52^{\star \star}$ & $\mathrm{p}<=8.79 \mathrm{e}-13$ *** \\
\hline 17 & Portfolio Size (\# Investees) / \# General Partners $<20$ & 1586 & 65.61 & 1.70 & 1431 & 101.38 & 22.07 & 0.87 & $\mathrm{p}<=8.73 \mathrm{e}-26$ *** \\
\hline Part D & Entrepreneurial Firm Characteristics & & & & & & & & \\
\hline 18 & Seed Stage & 146 & 8.88 & 0.00 & 71 & 520.37 & -2.92 & 1.01 & $\mathrm{p}<=0.097$ * \\
\hline 19 & Start-up Stage & 56 & 126.72 & 18.97 & 34 & 48.58 & -11.45 & $-1.65^{\star}$ & $p<=0.127$ \\
\hline 20 & Early Stage & 672 & 39.55 & 0.00 & 424 & -1.52 & -29.14 & $-2.93^{\star * *}$ & $\mathrm{p}<=3.24 \mathrm{e}-33 * * *$ \\
\hline 29 & Industry Market / Book $<5$ & 1173 & 15.42 & 7.92 & 1603 & 62.76 & 20.28 & $2.01^{* *}$ & $p<=1.3 e-28 * * *$ \\
\hline Part E & Investment Characteristics & & & & & & & & \\
\hline 30 & Lead Investment & 864 & 75.01 & 8.33 & 633 & 45.11 & 20.33 & -1.21 & $\mathrm{p}<=4.74 \mathrm{e}-07$ *** \\
\hline 31 & Syndicated Investment & 729 & 68.11 & 0.00 & 449 & 151.27 & 15.88 & 1.01 & $\mathrm{p}<=1.84 \mathrm{e}-05^{* * *}$ \\
\hline 32 & Co-Investment & 526 & 44.51 & 0.00 & 313 & 48.02 & 13.27 & 0.13 & $\mathrm{p}<=2.76 \mathrm{e}-05^{* * *}$ \\
\hline 33 & VC Board Seat(s) & 743 & 42.84 & 0.00 & 447 & 112.40 & 0.26 & 0.84 & $\mathrm{p}<=4.46 \mathrm{e}-13^{* * *}$ \\
\hline 34 & $\begin{array}{l}\text { Convertible Security with Actual Periodic Cash Flows } \\
\text { Standard Deviation of Cash Flows to Entrepreneur / }\end{array}$ & 967 & 123.03 & 12.77 & 1162 & 73.62 & 25.99 & -0.95 & $\mathrm{p}<=8.9 \mathrm{e}-32 * * *$ \\
\hline 35 & $\begin{array}{l}\text { Initial \$ Invested } \\
\text { Standard Deviation of Cash Flows to Entrepreneur / }\end{array}$ & 1203 & 130.12 & 0.00 & 1364 & 125.85 & 31.49 & -0.04 & $\mathrm{p}<=1.46 \mathrm{e}-62 * * *$ \\
\hline 36 & Initial \$ Invested & 1418 & 6.47 & 2.92 & 1055 & -5.26 & 0.33 & $-3.06^{* * *}$ & $\mathrm{p}<=0.216$ \\
\hline 37 & Initial Amount Invested > \$US 2,500,000 & 1310 & 34.62 & 5.04 & 1040 & 75.58 & 25.22 & 1.09 & $\mathrm{p}<=9.01 \mathrm{e}-54 * * *$ \\
\hline 38 & Initial Amount Invested < \$US 2,500,000 & 1311 & 91.80 & 0.00 & 1379 & 63.46 & 8.60 & -0.75 & $\mathrm{p}<=6.45 \mathrm{e}-34 * * *$ \\
\hline
\end{tabular}


Table 3. Correlation Matrix

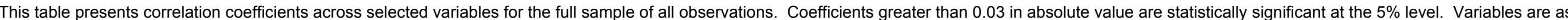
defined in Table 1.

\begin{tabular}{|c|c|c|c|c|c|c|c|c|c|c|c|c|c|c|c|c|c|c|c|c|}
\hline & & $(1)$ & (2) & (3) & (4) & (5) & (6) & (7) & $(8)$ & (9) & (10) & (11) & (12) & (13) & (14) & (15) & (16) & (17) & (18) & (19) \\
\hline (1) & $\log (\mathrm{IRR})$ & 1.00 & & & & & & & & & & & & & & & & & & \\
\hline (2) & $\log (\mathrm{MSCl})$ & -0.05 & 1.00 & & & & & & & & & & & & & & & & & \\
\hline (3) & Log (Interest) & -0.08 & 0.05 & 1.00 & & & & & & & & & & & & & & & & \\
\hline (4) & Log (Legality) & 0.03 & 0.03 & -0.02 & 1.00 & & & & & & & & & & & & & & & \\
\hline (5) & Log (Committed Capital) & 0.04 & -0.52 & -0.05 & -0.12 & 1.00 & & & & & & & & & & & & & & \\
\hline (6) & Log (Fund Number) & 0.01 & -0.08 & -0.06 & -0.18 & 0.31 & 1.00 & & & & & & & & & & & & & \\
\hline$(7)$ & Log (Portfolio Size / Manager) & -0.05 & 0.12 & 0.06 & -0.11 & -0.05 & 0.27 & 1.00 & & & & & & & & & & & & \\
\hline (8) & Seed & -0.05 & -0.10 & -0.03 & 0.00 & 0.10 & 0.04 & -0.08 & 1.00 & & & & & & & & & & & \\
\hline (9) & Early & -0.12 & -0.07 & -0.01 & -0.16 & 0.16 & 0.29 & 0.29 & -0.13 & 1.00 & & & & & & & & & & \\
\hline (10) & Expansion & 0.02 & 0.03 & 0.02 & 0.00 & -0.04 & 0.04 & 0.03 & -0.08 & -0.19 & 1.00 & & & & & & & & & \\
\hline (11) & Late & 0.02 & 0.02 & 0.03 & -0.04 & 0.04 & 0.07 & 0.08 & -0.05 & -0.12 & -0.07 & 1.00 & & & & & & & & \\
\hline$(12)$ & Log (Industry Market / Book) & -0.07 & -0.13 & -0.03 & 0.09 & 0.23 & 0.12 & -0.01 & 0.13 & 0.22 & -0.01 & 0.04 & 1.00 & & & & & & & \\
\hline (13) & Lead Investor & 0.03 & 0.00 & -0.01 & 0.06 & 0.08 & -0.19 & 0.07 & 0.11 & -0.07 & -0.03 & -0.07 & 0.04 & 1.00 & & & & & & \\
\hline (14) & Syndicated Investment & 0.04 & -0.04 & -0.07 & 0.05 & 0.13 & -0.08 & 0.07 & 0.16 & 0.15 & -0.07 & 0.05 & 0.20 & 0.06 & 1.00 & & & & & \\
\hline (15) & Co-Investment & -0.01 & -0.08 & 0.04 & -0.19 & 0.12 & 0.18 & 0.07 & -0.01 & 0.12 & 0.03 & 0.07 & 0.09 & -0.10 & 0.03 & 1.00 & & & & \\
\hline (16) & Board Seats & -0.04 & -0.11 & -0.03 & 0.06 & 0.11 & -0.06 & 0.02 & 0.19 & 0.17 & -0.01 & -0.06 & 0.23 & 0.33 & 0.29 & 0.09 & 1.00 & & & \\
\hline (17) & Convertible Security & 0.27 & 0.19 & 0.01 & 0.03 & -0.26 & -0.25 & -0.04 & -0.13 & -0.31 & 0.02 & -0.11 & -0.33 & 0.11 & -0.11 & -0.10 & -0.14 & 1.00 & & \\
\hline$(18)$ & Standard Deviation of Cash Flows & 0.01 & 0.02 & 0.03 & 0.00 & -0.02 & 0.00 & 0.00 & -0.01 & -0.01 & -0.01 & -0.01 & -0.01 & -0.02 & -0.02 & -0.01 & -0.01 & 0.03 & 1.00 & \\
\hline (19) & Log (Initial Investment) & 0.11 & -0.04 & -0.02 & 0.03 & 0.09 & 0.05 & -0.08 & -0.23 & -0.24 & 0.04 & 0.06 & -0.24 & -0.01 & -0.15 & -0.02 & -0.23 & 0.22 & -0.16 & 1.00 \\
\hline
\end{tabular}




\section{Table 4. Regression Analyses on the Determinants of Realized Returns}

Panel A. Seed, Start-up, Early and Expansion Stage Investments

This table presents OLS and Heckman $(1976,1979)$ corrected estimates of the determinants of realized venture capital IRRs. Models (1) and (2) are simple OLS models on the restricted sample of fully realized exits for the subsample of venture capital investments. Models (3) and (4) present Heckman corrected estimates on the sample of all venture capital investments. The Heckman corrections involve a first step bivariate probit model to select fully realized exits (as opposed to no exit, or a partial exit), in order to assess the incidental truncation of observed IRRs. The sample in the second step is based on the selection in the first step. The full sample of all exited and unexited (or partially exited) investments comprises 3213 observations from 39 countries. Observations skipped where incomplete data for the transaction. One observation is per entrepreneurial firm, not per staged investment round. The regression coefficients (only) are presented. ${ }^{*},{ }^{* *},{ }^{\star \star *}$ Significant at the $10 \%, 5 \%$ and $1 \%$ levels, respectively. Variables are as defined in Table 1.

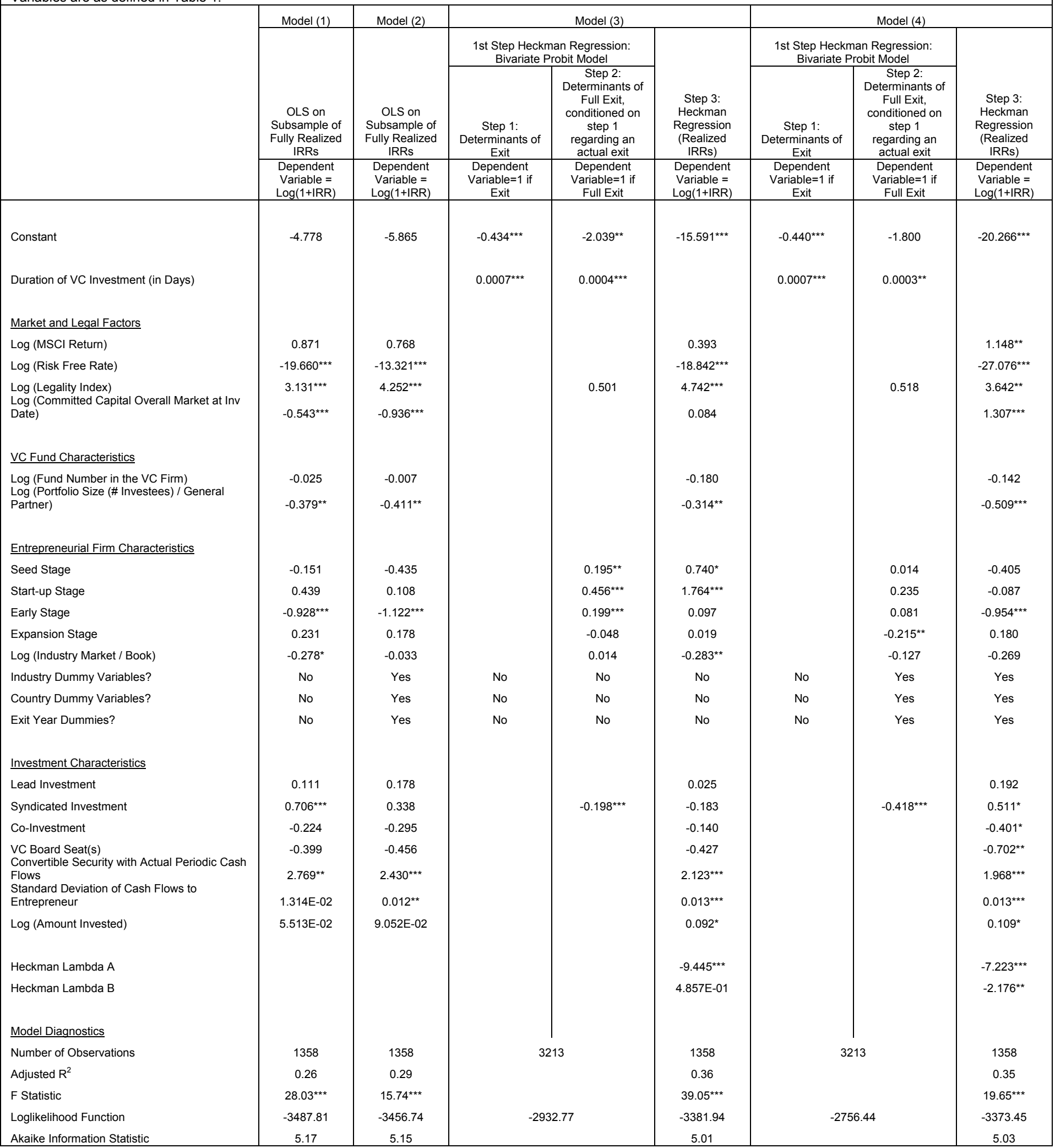


Table 4. Regression Analyses on the Determinants of Realized Returns

Panel B. All Types of Venture Capital and Private Equity Investment

This table presents OLS and Heckman $(1976,1979)$ corrected estimates of the determinants of realized venture capital and private equity IRRs. Models (1) and (2) are simple OLS models on the restricted sample of fully realized exits for the subsample of venture capital and private equity investments. Models (3) and (4) present Heckman corrected estimates on the sample of all venture capital and private equity investments. The Heckman corrections involve a first step bivariate probit model to select fully realized exits (as opposed to no exit, or a partial exit), in order to assess the incidental truncation of observed IRRs. The sample in the second step is based on the selection in the first step. The full sample of all exited and unexited (or partially exited) investments comprises 5038 observations from 39 countries. Observations skipped where incomplete data for the transaction. One observation is per entrepreneurial firm, not per staged investment round. The regression coefficients (only) are presented. ${ }^{*},{ }^{* *},{ }^{* * *}$ Significant at the $10 \%, 5 \%$ and $1 \%$ levels, respectively. Variables are as defined in Table 1.

Constant

Duration of VC Investment (in Days)

Market and Legal Factors

Log (MSCI Return)

Log (Risk Free Rate)

Log (Legality Index)

Log (Committed Capital Overall Market at Inv Date)

VC Fund Characteristics

Log (Fund Number in the VC Firm)

Log (Portfolio Size (\# Investees) / General Partner)

Entrepreneurial Firm Characteristics

Seed Stage

Start-up Stage

Early Stage

Expansion Stage

Late Stage

$\mathrm{MBO} / \mathrm{MBI}$

LBO

Publicly Listed Company

Turnaround

Secondary Trade

Log (Industry Market / Book)

Industry Dummy Variables?

Country Dummy Variables?

Year of Exit Dummy Variables?

Investment Characteristics

Lead Investment

Syndicated Investment

Co-Investment

VC Board Seat(s)

Convertible Security with Actual Periodic Cash Flows

Standard Deviation of Cash Flows to Entrepreneur

Log (Amount Invested)

Heckman Lambda A

Heckman Lambda B

Model Diagnostics

Number of Observations

Adjusted $\mathrm{R}^{2}$

F Statistic

Loglikelihood Function

Akaike Information Statistic

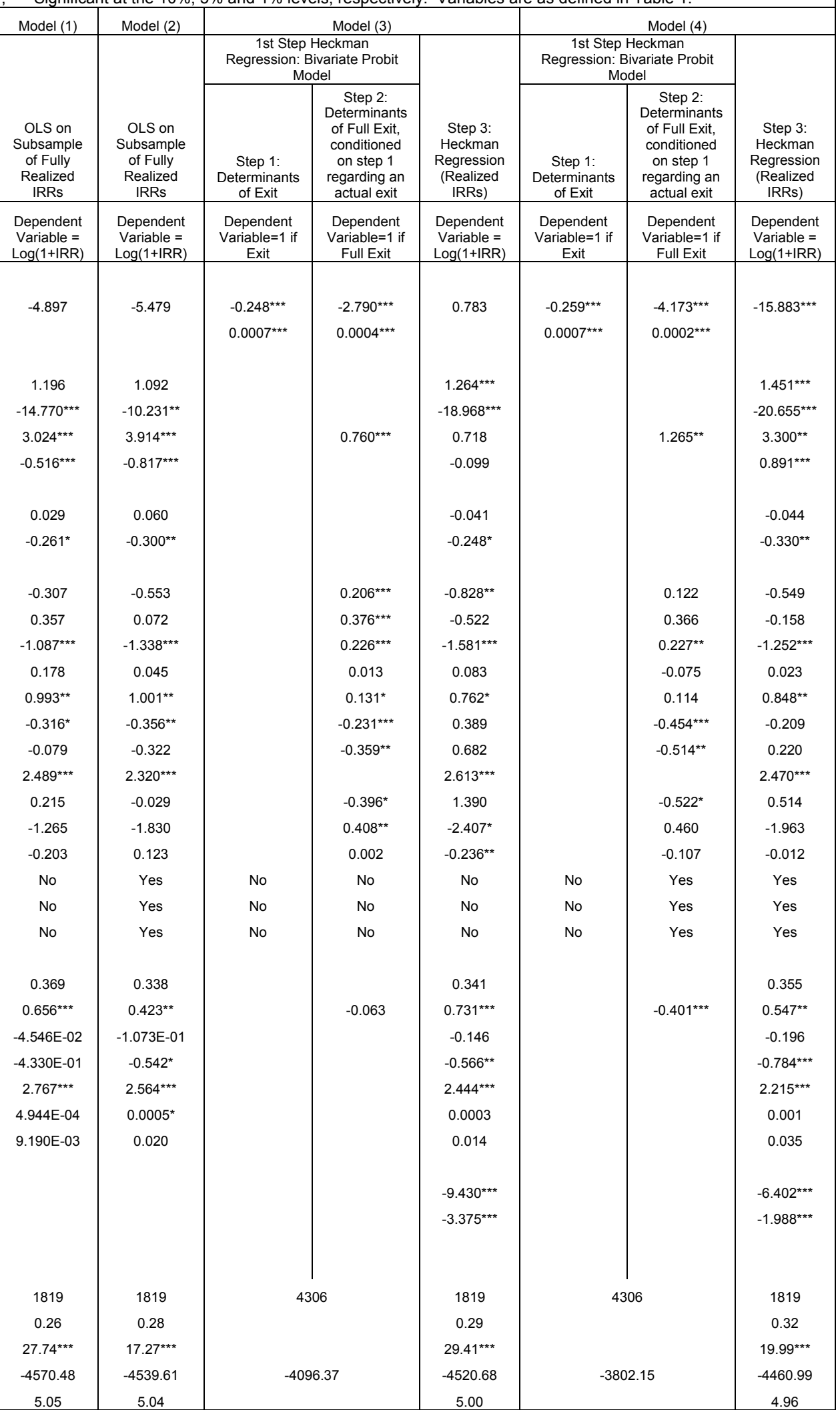


Table 5. Determinants of the Difference between Unrealized IRRs Disclosed to Investment Managers and Predicted IRRs

Panel A. Seed, Start-up, Early and Expansion Stage Investments

This table presents OLS estimates of the determinants of the difference between the unrealized reported IRRs and the predicted IRRs based on the Models for realized IRRs in Table 4 Panel A. The Model numbers correspond to the Model numbers in Table 4 Panel A in regards to the models used to create the fitted values for predicted returns for unrealized investments. One observation is per entrepreneurial firm, not per staged investment round. Observations are excluded where a variable is used in the particular specification is not observed (due to private confidential information). The number of observations corresponds to the number of unexited investments. The regression coefficients (only) are presented. ${ }^{*},{ }^{* *}$, ${ }^{* *}$ Significant at the $10 \%, 5 \%$ and $1 \%$ levels, respectively. The variables are as defined in Table 1.

Constant

\section{Market and Legal Factors}

Log (MSCI Return)

Log (Risk Free Rate)

Log (Legality Index)

Country Earnings Aggressiveness Index

Log (Country Disclosure Level Index)

\section{VC Fund Characteristics}

Log (Age of VC Fund within the VC Firm)

Log (Portfolio Size (\# Investees) / General Partner)

Entrepreneurial Firm Characteristics

Seed Stage

Start-up Stage

Early Stage

Expansion Stage

Log (Industry Market / Book)

Industry Dummy Variables?

Country Dummy Variables?

\section{$\underline{\text { Investment Characteristics }}$}

Lead Investment

Syndicated Investment

Co-Investment

VC Board Seat(s)

Convertible Security with Actual Periodic Cash Flows

Standard Deviation of Cash Flows to Entrepreneur

Log (Amount Invested)

Model Diagnostics

Number of Observations

Adjusted $\mathrm{R}^{2}$

F Statistic

Loglikelihood Function

Akaike Information Statistic

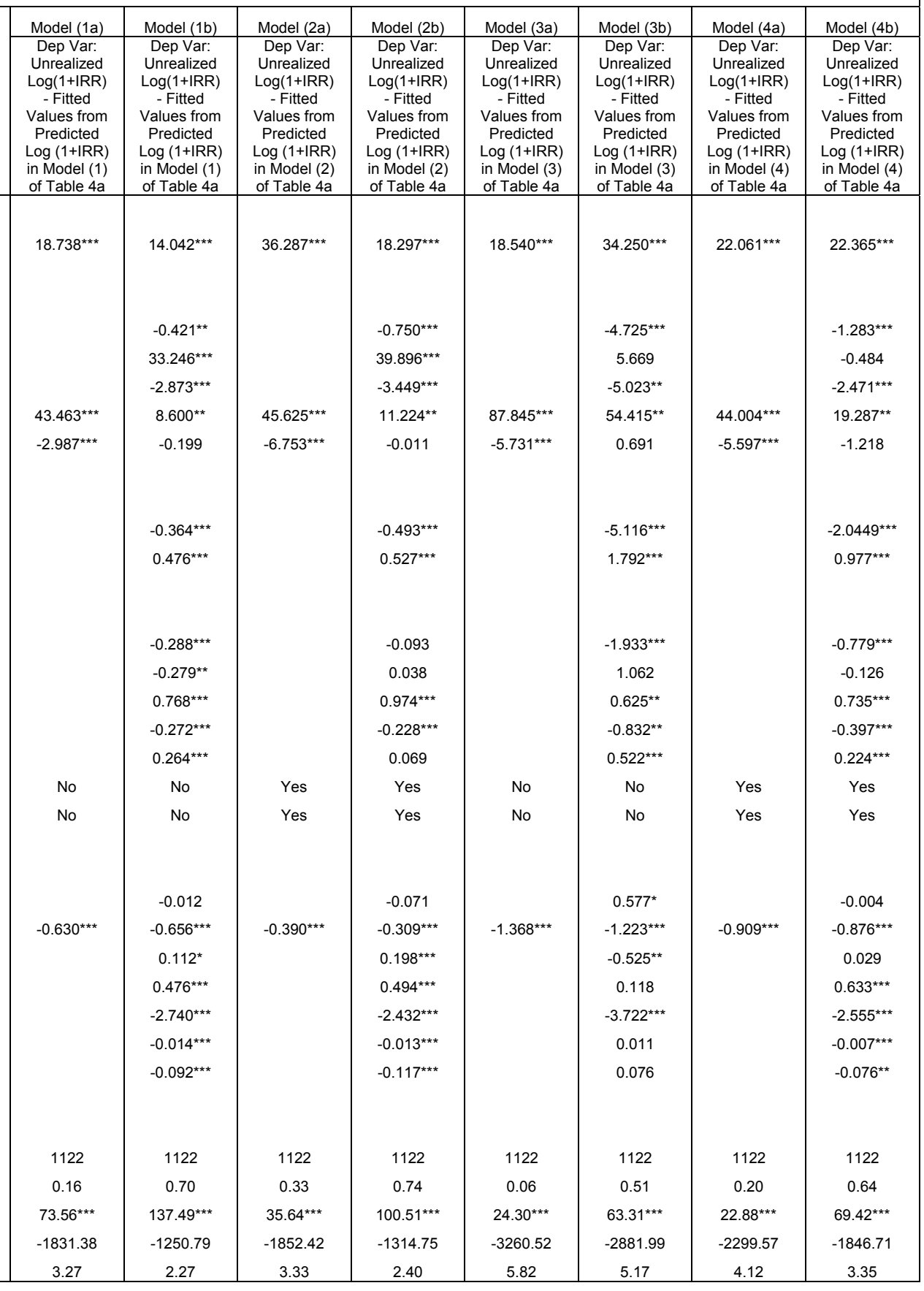


Table 5. Determinants of the Difference between Unrealized IRRs Disclosed to Investment Managers and Predicted IRRs

Panel B. All Types of Venture Capital and Private Equity Investment

This table presents OLS estimates of the determinants of the difference between the unrealized reported IRRs and the predicted IRRs based on the Models for realized IRRs in Table 4 Panel B. The Model numbers correspond to the Model numbers in Table 4 Panel B in regards to the models used to create the fitted values for predicted returns for unrealized investments. One observation is per entrepreneurial firm, not per staged investment round. Observations are excluded where a variable is used in the particular specification is not observed (due to private confidential information). The number of observations corresponds to the number of unexited investments. The regression coefficients (only) are presented. ${ }^{*},{ }^{* *}$, ${ }^{* *}$ Significant at the $10 \%, 5 \%$ and $1 \%$ levels, respectively. The variables are as defined in Table 1.

Constant

\section{Market and Legal Factors}

Log (MSCI Return)

Log (Risk Free Rate)

Log (Legality Index)

Country Earnings Aggressiveness Index

Log (Country Disclosure Level Index)

\section{VC Fund Characteristics}

Log (Age of VC Fund within the VC Firm)

Log (Portfolio Size (\# Investees) / General Partner)

Entrepreneurial Firm Characteristics

Seed Stage

Start-up Stage

Early Stage

Expansion Stage

Late Stage

$\mathrm{MBO} / \mathrm{MBI}$

LBO

Publicly Listed Company

Log (Industry Market / Book)

Industry Dummy Variables?

Country Dummy Variables?

Investment Characteristics

Lead Investment

Syndicated Investment

Co-Investment

VC Board Seat(s)

Convertible Security with Actual Periodic Cash Flows Standard Deviation of Cash Flows to Entrepreneur

Log (Amount Invested)

Model Diagnostics

Number of Observations

Adjusted $\mathrm{R}^{2}$

F Statistic

Loglikelihood Function

Akaike Information Statistic

\begin{tabular}{|c|c|c|c|c|c|c|c|}
\hline Model (1a) & Model (1b) & Model (2a) & Model (2b) & Model (3a) & Model (3b) & Model (4a) & Model (4b) \\
\hline Dep Var: & Dep Var: & Dep Var: & Dep Var: & Dep Var: & Dep Var: & Dep Var: & Dep Var: \\
\hline Unrealized & Unrealized & Unrealized & Unrealized & Unrealized & Unrealized & Unrealized & Unrealized \\
\hline $\log (1+I R R)$ & $\log (1+I R R)$ & $\log (1+\operatorname{IRR})$ & $\log (1+\operatorname{IRR})$ & $\log (1+I R R)$ & $\log (1+\operatorname{IRR})$ & $\log (1+I R R)$ & $\log (1+I R R)$ \\
\hline - Fitted & - Fitted & - Fitted & - Fitted & - Fitted & - Fitted & - Fitted & - Fitted \\
\hline $\begin{array}{l}\text { Values from } \\
\text { Predicted }\end{array}$ & $\begin{array}{l}\text { Values from } \\
\text { Predicted }\end{array}$ & $\begin{array}{l}\text { Values from } \\
\text { Predicted }\end{array}$ & $\begin{array}{l}\text { Values from } \\
\text { Predicted }\end{array}$ & $\begin{array}{l}\text { Values from } \\
\text { Predicted }\end{array}$ & $\begin{array}{l}\text { Values from } \\
\text { Predicted }\end{array}$ & $\begin{array}{l}\text { Values from } \\
\text { Predicted }\end{array}$ & $\begin{array}{l}\text { Values from } \\
\text { Predicted }\end{array}$ \\
\hline $\log (1+\operatorname{IRR})$ & $\log (1+$ IRR $)$ & $\log (1+\operatorname{IRR})$ & $\log (1+I R R)$ & $\log (1+I R R)$ & $\log (1+$ IRR $)$ & $\log (1+\operatorname{IRR})$ & $\log (1+I R R)$ \\
\hline $\begin{array}{l}\text { in Model (1) } \\
\text { of Table } 4 \mathrm{~b}\end{array}$ & $\begin{array}{l}\text { in Model (1) } \\
\text { of Table } 4 \mathrm{~b}\end{array}$ & $\begin{array}{l}\text { in Model (2) } \\
\text { of Table 4b }\end{array}$ & $\begin{array}{l}\text { in Model (2) } \\
\text { of Table 4b }\end{array}$ & $\begin{array}{l}\text { in Model (3) } \\
\text { of Table 4b }\end{array}$ & $\begin{array}{l}\text { in Model (3) } \\
\text { of Table 4b }\end{array}$ & $\begin{array}{l}\text { in Model (4) } \\
\text { of Table 4b }\end{array}$ & $\begin{array}{l}\text { in Model (4) } \\
\text { of Table 4b }\end{array}$ \\
\hline \multirow[t]{4}{*}{$18.869^{\star \star \star}$} & $11.664^{\star \star *}$ & $31.353^{\star \star \star}$ & $18.118^{\star * *}$ & $12.327^{\star \star \star}$ & $22.878^{\star \star *}$ & $15.270^{\star \star \star}$ & $18.108^{\star \star \star}$ \\
\hline & $-1.304^{\star \star *}$ & & $-1.061^{\star \star *}$ & & $-4.526^{\star \star \star}$ & & $-1.941^{\star \star \star}$ \\
\hline & $25.472^{\text {***}}$ & & $32.485^{\star \star \star}$ & & 10.707 & & $-15.943^{\text {***}}$ \\
\hline & $-2.517^{\star \star \star}$ & & $-3.377^{\star \star *}$ & & -2.395 & & $-2.318^{\star * *}$ \\
\hline $41.993^{\star \star \star}$ & $10.713^{* \star *}$ & $38.932^{\star \star *}$ & $8.643^{\star *}$ & $67.756^{\star \star \star}$ & $45.045^{\star \star \star}$ & $44.490^{\star \star \star}$ & $22.134^{\star *}$ \\
\hline \multirow[t]{12}{*}{$-3.118^{\star \star \star}$} & -0.515 & $-5.795^{\star \star \star}$ & -0.504 & $-4.279^{\star \star \star}$ & 0.253 & $5.051^{* \star \star}$ & -1.226 \\
\hline & -0.044 & & $-0.418^{\star \star \star}$ & & $-4.058^{\star \star *}$ & & $-2.059^{\star \star \star}$ \\
\hline & $0.323^{\star \star \star}$ & & $0.358^{\star \star \star}$ & & $1.297^{\star \star \star}$ & & $0.860^{\star \star \star}$ \\
\hline & -0.028 & & 0.061 & & $-1.289^{* \star *}$ & & $-0.682^{\star \star \star}$ \\
\hline & -0.140 & & 0.116 & & -0.524 & & 0.230 \\
\hline & $0.973^{\text {*** }}$ & & $1.226^{* \star *}$ & & $1.213^{\star \star * *}$ & & $1.060^{\star \star \star}$ \\
\hline & $-0.190^{\star \star *}$ & & -0.053 & & -0.390 & & -0.158 \\
\hline & $-0.924^{\star \star \star}$ & & $-0.930^{\star \star *}$ & & -0.489 & & $-0.634^{\star \star *}$ \\
\hline & $0.325^{\star \star \star}$ & & $0.279^{\star \star \star}$ & & -0.462 & & -0.291 \\
\hline & 0.201 & & $0.526^{\star *}$ & & -0.401 & & -0.427 \\
\hline & $-1.839^{\star \star *}$ & & $-1.677^{\text {***}}$ & & -0.184 & & $-0.937^{\star * \star}$ \\
\hline & $0.220^{* \star *}$ & & -0.084 & & $0.470^{\star \star \star}$ & & 0.052 \\
\hline No & No & Yes & Yes & No & No & Yes & Yes \\
\hline \multirow[t]{2}{*}{ No } & No & Yes & Yes & No & No & Yes & Yes \\
\hline & $-0.265^{\star \star *}$ & & $-0.204^{\star \star *}$ & & 0.205 & & -0.101 \\
\hline \multirow[t]{6}{*}{$-0.193^{\star \star \star}$} & $-0.588^{\star \star \star}$ & $-0.485^{\star \star \star}$ & $-0.351^{\text {***}}$ & $-1.107^{\star \star \star}$ & $-1.106^{\star \star *}$ & $-0.817^{\star * *}$ & $-0.779^{\star \star \star}$ \\
\hline & -0.083 & & 0.024 & & $-0.354^{*}$ & & -0.132 \\
\hline & $0.494^{* \star *}$ & & $0.554^{\star \star \star}$ & & -0.044 & & $0.577^{\text {***}}$ \\
\hline & $-2.785^{\star \star *}$ & & $-2.600^{* * *}$ & & $-3.902^{* * *}$ & & $-2.956^{* * *}$ \\
\hline & 0.000 & & 0.000 & & $0.005^{\star \star *}$ & & 0.001 \\
\hline & -0.023 & & $-0.042^{\star \star *}$ & & 0.034 & & -0.013 \\
\hline 1269 & 1269 & 1269 & 1269 & 1269 & 1269 & 1269 & 1269 \\
\hline 0.11 & 0.67 & 0.27 & 0.73 & 0.05 & 0.51 & 0.15 & 0.58 \\
\hline $53.05^{\star \star *}$ & $111.44^{* * *}$ & $30.42^{\text {***}}$ & $97.11^{\text {***}}$ & $24.10^{\star \star \star *}$ & $58.59^{* \star *}$ & $19.01^{\text {***}}$ & $54.01^{* * *}$ \\
\hline-2092.62 & -1423.82 & -2126.86 & -1475.24 & -3527.05 & -3094.42 & -2798.83 & -2342.70 \\
\hline 3.24 & 2.28 & 3.31 & 2.34 & 5.46 & 4.82 & 4.35 & 3.67 \\
\hline
\end{tabular}




\section{CFS Working Paper Series:}

\begin{tabular}{lll} 
No. & Author(s) & Title \\
\hline $2003 / 43$ & $\begin{array}{l}\text { William A. Brock } \\
\text { Steven N. Durlauf } \\
\text { Kenneth D. West }\end{array}$ & $\begin{array}{l}\text { Policy Evaluation in Uncertain Economic } \\
\text { Environments }\end{array}$ \\
$2003 / 44$ & $\begin{array}{l}\text { Timothy Cogley } \\
\text { Sergei Morozov } \\
\text { Thomas J. Sargent }\end{array}$ & $\begin{array}{l}\text { Bayesian Fan Charts for U.K. Inflation: } \\
\text { Forecasting and Sources of Uncertainty in an } \\
\text { Evolving Monetary System }\end{array}$ \\
& $\begin{array}{l}\text { Guenter W. Beck } \\
\text { No03/45 }\end{array}$ & $\begin{array}{l}\text { Nominal Exchange Rate Regimes and Relative } \\
\text { Price Dispersion: On the Importance of Nominal } \\
\text { Exchange Rate Volatility for the Width of the } \\
\text { Border }\end{array}$ \\
& $\begin{array}{l}\text { Michael Ehrmann } \\
\text { Marcel Fratzscher }\end{array}$ & $\begin{array}{l}\text { Equal size, equal role? } \\
\text { Interest rate interdependence between the euro } \\
\text { area and the United States }\end{array}$ \\
& & $\begin{array}{l}\text { IPOs Cycle and Investment in High-Tech } \\
\text { Industries }\end{array}$
\end{tabular}

2003/48 Martin D. Dietz

Screening and Advising by a Venture Capitalist with a Time Constraint

$\begin{array}{ll}\text { 2004/01 } & \begin{array}{l}\text { Ivica Dus } \\ \text { Raimond Maurer }\end{array}\end{array}$

Betting on Death and Capital Markets in Retirement: A Shortfall Risk Analysis of Life Olivia S. Mitchell

Annuities versus Phased Withdrawal Plans

Are IPOs of Different VCs Different?

2004/02 Tereza Tykvová Uwe Walz

2004/03 Marc Escrihuela-Villar

Innovation and Market Concentration with Asymmetric Firms

2004/04 Ester Faia

Tommaso Monacelli

Ramsey Monetary Policy and International

Relative Prices

2004/05 Uwe Wals

Douglas Cumming

Private Equity Returns and Disclosure around the World

Copies of working papers can be downloaded at http://www.ifk-cfs.de 